CINTHIA GABRIEL MEIRELES

AVALIAÇÃO DO EFEITO CITOTÓXICO DA METFORMINA EM LINHAGENS CELULARES DE ADENOCARCINOMA DE PRÓSTATA E DE FEOCROMOCITOMA. 


\author{
UNIVERSIDADE DE BRASÍLA \\ FACULDADE DE CIÊNCIAS DA SAÚDE \\ PROGRAMA DE PÓS-GRADUAÇÃO EM CIÊNCIAS DA SAÚDE
}

CINTHIA GABRIEL MEIRELES

\title{
AVALIAÇÃO DO EFEITO CITOTÓXICO DA METFORMINA EM LINHAGENS CELULARES DE ADENOCARCINOMA DE PRÓSTATA E DE FEOCROMOCITOMA.
}

Dissertação apresentada como requisito parcial para obtenção do Título de Mestre em Ciências da Saúde pelo Programa de Pós-Graduação em Ciências da Saúde da Universidade de Brasília.

\begin{tabular}{ll} 
Área de concentração: & \multicolumn{2}{c}{ de } \\
Farmacologia/Toxicologia e Produtos \\
Naturais
\end{tabular}

Orientador: Prof. Dr. Luiz Alberto Simeoni Co-Orientadora: Profa. Dra. Adriana Lofrano Alves Porto 
Autorizo a reprodução e divulgação total ou parcial deste trabalho, por qualquer meio convencional ou eletrônico, para fins de ensino, estudo ou pesquisa, desde que citada a fonte. 
CINTHIA GABRIEL MEIRELES

\title{
AVALIAÇÃO DO EFEITO CITOTÓXICO DA METFORMINA EM LINHAGENS CELULARES DE ADENOCARCINOMA DE PRÓSTATA E DE FEOCROMOCITOMA.
}

\begin{abstract}
Dissertação apresentada como requisito parcial para obtenção do Título de Mestre em Ciências da Saúde pelo Programa de Pós-graduação em Ciências da Saúde da Universidade de Brasília.

Área de concentração: Farmacologia e Toxicologia.
\end{abstract}

Aprovado em: 13 de fevereiro de 2015

BANCA EXAMINADORA

Prof. Dr. Luiz Alberto Simeoni - presidente Universidade de Brasília

Prof. Dr. Augusto Cezar Florêncio Costa Universidade de Brasília

Profa. Dra. Maria de Fátima de Borin Universidade de Brasília 
Dedico o meu trabalho a Deus, à Nossa Senhora do Carmo e a minha amada família. 


\section{AGRADECIMENTOS}

A Deus e nossa senhora do Carmo que me deram força para sempre seguir em frente.

À minha mãe Maize e ao meu pai Antônio pelo amor, apoio, dedicação e suporte para meus estudos. Às minhas irmãs Camila e Carina pela ajuda e companheirismo. À minha vó, meus tios e tias, primos e primas, muito obrigada pela força, apoio e amizade.

Aos meus orientadores, professor Luiz e a professora Adriana, meus amigos, meus exemplos. Muito obrigada pela oportunidade, por tudo que me foi ensinado durante 0 mestrado e pela confiança.

Aos colegas e amigos do FarMol em especial: Bia, Olivia, Carol Martins, Fernanda, Nadyellem, Yasmim, Carol Lourenço, Flora, Mariella, Erica, Sidney, Sarah e a todos os professores do FarMol pela ajuda e amizade.

A todos do Laboratório de Histopatologia Bucal da Universidade de Brasília em especial à professora Eliete Neves e à professora Ana Carolina por conceder o espaço para realização dos experimentos, pelo apoio e ajuda. À Dani, Silvinha e Gabriel meu sincero agradecimento por toda ajuda e pela amizade.

Ao Laboratório de Biologia Celular e Molecular de Universidade de Campinas, Professor Ricardo Coletta e Fábio Haach Téo pela ajuda na leitura dos experimentos do ciclo celular.

Ao CNPq (Conselho Nacional de Desenvolvimento Científico e Tecnológico) pelo auxílio bolsa e verba para realização da pesquisa. 
"Todo caminho da gente é resvaloso. Mas também, cair não prejudica demais a gente levanta, a gente sobe, a gente volta!... O correr da vida embrulha tudo, a vida é assim: esquenta, esfria, aperta e daí afrouxa, sossega e depois desinquieta. O que ela quer da gente é CORAGEM." 
RESUMO

O câncer é uma doença que acomete diferentes órgãos do organismo, com comportamento biológico variável. $\mathrm{O}$ adenocarcinoma de próstata corresponde a $10 \%$ do total de cânceres. O feocromocitoma é um tumor neuroendócrino derivado de células cromafins que se encontram na medula da glândula supra-renal. Tem sido descrito efeito inibidor da metformina sobre sobrevivência e crescimento celular, in vitro, em algumas linhagens celulares de câncer. O presente estudo tem como objetivo investigar o efeito citotóxico da metformina em linhagens celulares de adenocarcinoma de próstata humano e de feocromocitoma de ratos. Foram utilizadas duas linhagens de adenocarcinoma de próstata humano, LNCaP (andrógeno-sensível) e PC3 (andrógeno-resistente) e células de feocromocitoma, PC12-Adh. Foi utilizado o ensaio de MTT para a determinar a viabilidade celular antes, após tratamentos e na associação de fármacos. Para avaliar se metformina altera o ciclo celular da linhagem PC12-Adh foi realizado ensaio com citometria de fluxo, usando concentrações de $20,85 \mathrm{mM}$ de metformina e $8,23 \mu \mathrm{M}$ de sunitinib. Por meio de Western Blot, foi avaliado se a metformina altera a expressão de proteínas pró-apoptóticas. Os resultados mostraram que a metformina inibiu a viabilidade de ambas as linhagens celulares de adenocarcinoma de próstata, LNCaP e PC3. A metformina também inibiu a viabilidade das células PC12-Adh, com efeito de magnitude semelhante ao sunitinib. Não foi observado efeito sinérgico ou potencialização do efeito do sunitinib sobre a inibição da viabilidade celular em células de feocromocitoma, quando foi adicionada metformina. Esse resultado sugeriu possível interação entre os dois fármacos, onde o efeito do sunitinib foi aparentemente impedido quando as células foram tratadas com metformina concomitantemente. $O$ tratamento com metformina na concentração de 20,85mM por $48 \mathrm{~h}$ não alterou o ciclo celular. Contudo, nessas mesmas condições, houve um aumento da expressão de proteína caspase 3, sugerindo indução de apoptose. Os resultados sugerem que a metformina inibe a viabilidade das células LNCaP de forma mais intensa que das células PC3, sugerindo que esse efeito possa ser mediado pelo receptor de andrógeno. A metformina inibe a viabilidade das células PC12Ahc, nas concentrações utilizadas, em magnitude semelhante à induzida pelo sunitinib. Observou-se possível interação entre metformina e sunitinib, in vitro, caracterizada pela interferência com o efeito do sunitinib induzida pela adição de metformina nas menores concentrações. A metformina não interfere no ciclo celular das células PC12-Adh após 48 horas de tratamento, porém induz aumento da expressão caspase 3 , sugerindo efeito pró-apoptótico. 
PALAVRAS-CHAVE: adenocarcinoma de câncer; feocromocitoma; metformina; bicalutamida; sunitinib ABSTRACT

Cancer is a disease that affects different organs and displays with variable biological behavior. Prostate adenocarcinoma accounts for $10 \%$ of all cancers. Pheochromocytoma is a neuroendocrine tumor derived from chromaffin cells situated in adrenal medulla. It has been reported inhibitory effect, in vitro, of metformin on survival and growth of some cancer cell lines. The present study aims to investigate the cytotoxic effect of metformin on human prostate adenocarcinoma and rats pheochromocytoma cell lines. Were used two human prostate adenocarcinoma cells lines, LNCaP (androgensensitive) and PC3 (androgen-resistant), and pheochromocytoma cell line PC12-Adh. The MTT assay is used to determined cell viability before and after treatment and metformin with sunitinib combination. To assess whether metformin changes cell cycle of PC12-Adh, the flow cytometry was performed, using metformin $20,85 \mathrm{mM}$ and sunitinib $8,23 \mu \mathrm{M}$ in PC12-Adh cells. Western blot was used to determinate if metformin alter the expression of pro-apoptotic proteins. The results show that metformin inhibited the cell viability in both prostate adenocarcinoma cell lines, LNCaP and PC3. Metformin also inhibited PC12-Adh cells viability similarly to sunitinib. There was no change in the inhibition of viability in pheochromocytoma cells induced by sunitinib when metformin was added, suggesting an inhibitory effect of metformin upon suntinib. This result suggested a possible interaction between these two drugs, where the effect of sunitinib was apparently prevented when the cells were concurrently treated with metformin. Treatment with metformin in the concentration of $20,85 \mathrm{mM}$ for 48 hours did not alter the cell cycle. However, under these same conditions, there was an increase in caspase-3 protein expression, suggesting apoptosis. The results that metformin inhibits the viability of $\mathrm{LNCaP}$ cells more intensely compared to PC3 cells, suggesting that this effect may be mediated by the androgen receptor. Metformin inhibits viability of PC12-Adh cells, in similar concentrations those induced by sunitinib. We propose a possible interaction between metformin and sunitinib in vitro, characterized by interference with the effect of sunitinib induced by the addition of metformin in lower concentrations and although metformin does not interfere with $\mathrm{P}^{n+1} \mathrm{n}$ Adh cell cycle after 48 hours of treatment, it leads to increased expression of caspe suggesting a pro-apoptotic effect.

KEYWORDS: adenocarcinoma cancer; pheochromocytoma; metformin; bicalutamide; sunitinib 


\section{LISTA DE FIGURAS}

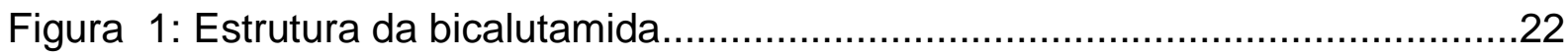

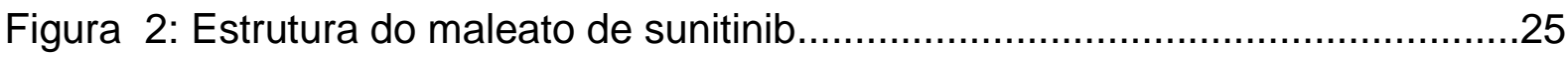

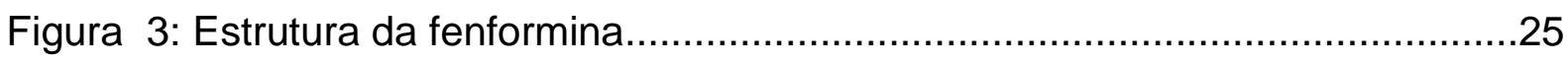

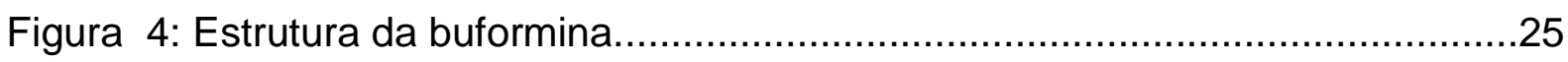

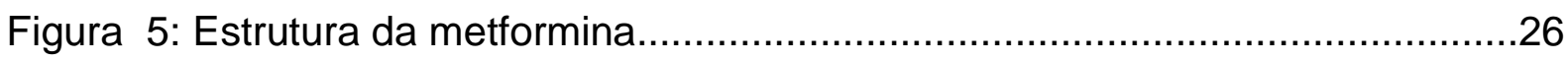

Figura 6: Cadeia de transporte de elétrons e fosforilação oxidativa..................... 32

Figura 7: Ativação de AMPK e inibição de mTOR como alvos farmacológicos principais ......................................................................................

Figura 8: Inibição da sinalização induzida por fatores de crescimento (insulina e IGF1) e por receptores acoplados à proteína G (GPCR) ........................35

Figura 9: Ensaio de viabilidade celular por MTT com células LNCaP tratadas com metformina e bicalutamida.

Figura 10: Ensaio de viabilidade celular por MTT com células PC3 tratadas com metformina e bicalutamida.

Figura 11: Ensaio de viabilidade celular por MTT com células PC12-Adh tratadas com metformina e sunitinib.

Figura 12: Efeito da associação de metformina e sunitinib sobre a viabilidade das células PC12-Adh.

Figura 13: Ensaio de avaliação do ciclo das células PC12-Adh tratadas com metformina.

Figura 14: Ensaio da avaliação do ciclo das células PC12-Adh tratadas com sunitinib

Figura 15: Ensaio da avaliação da expressão da proteína caspase 3 da via da apoptose das células PC12-Adh tratadas com metformina.

Figura 16: Ensaio da avaliação da expressão da proteína caspase 3 da via da apoptose das células PC12-Adh tratadas com sunitinib. 


\section{LISTA DE TABELAS}

Tabela 1: Características das linhagens celulares.............................................. 39

Tabela 2: Concentrações dos tratamentos utilizados no ensaio de viabilidade celular com MTT ................................................................................. 41

Tabela 3: $\mathrm{Cl}_{50}$ e inibição máxima da viabilidade das linhagens celulares de adenocarcinoma de próstata e de feocromocitoma tratadas, utilizando o

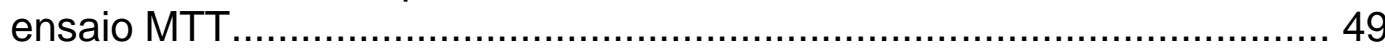

Tabela 4: Associação de metformina em concentrações crescentes e sunitinib em concentrações fixas $8,23 \mu \mathrm{M}$ e $20 \mu \mathrm{M}$ em 24 e 48 horas. 


\section{LISTA DE ABREVIATURAS E SIGLAS}

1a PGC-Peroxisome proliferator-activated receptor gamma coactivator 1-alpha Acetil CoA-Acetil coenzime $A$

ADP- adenosine diphosphate - difosfato de adenosina

AKT- serine/threonine protein kinase Akt

AMP- adenosine monophosphate - monofosfato de adenosina

AMPK- adenosine monophosphate-activated protein kinase - proteína quinase ativada por AMP

AR- androgen receptor - receptor de andrógenos

ATP- adenosine monophosphate - trifosfato de adenosina

BCRJ- Banco de células do Rio de Janeiro

BSA- bovine serum albumin - albumina do soro bovino

Bic- bicalutamida

CaMKK2- calcium/calmodulin-dependent protein kinase kinase 2 - proteína quinase 2 dependente de cálcio calmodulina

cAMP- Cyclic adenosine monophosphate - monofosfato cíclico de adenosina

c-kit- Stem cell fator - receptores de células-tronco

$\mathrm{Cl}_{50}-50 \%$ da concentração inibitória máxima

CYP3A4- Cytochrome P450 3A4 - citocromo P450 3A4

CoQ- Coenzima $Q$ - coenzima $Q$

DMSO:EtOH- Dimethyl sulfoxide:ethanol - Dimetilsufóxido:etanol

DNA- Deoxyribonucleic acid

EPM- erro padrão

ERK- extracellular signal-regulated kinases - quinase que regula o sinal extracelular

ERa- estrogen receptor $\alpha$ - receptor de estrógeno do tipo $\alpha$

ER $\beta$ - estrogen receptor $\beta$ - receptorde estrógeno do tipo $\beta$

FACS- Fluorescence-activated cell sorting

FADH2- Flavin adenine dinucleotide - Dinucleótido de flavina e adenina Reduzida

FDA- Food and Drug Administration

GAPDH - Glyceraldehyde 3-phosphate dehydrogenase

GDP- Guanosine diphosphate - Guanosina difosfato

GLP1- Glucagon-like peptide-1 - peptídeo semelhante ao glucagon 1 
GLUT 1- Glucose transporter 1 - transportador de glicose 1

GLUT 4- Glucose transporter 4 - transportador de glicose 4

$\mathrm{GnRH}$ - Gonadotropin-releasing hormone - Hormônio liberador de gonadotrofina

GPCR- G protein-coupled receptors - receptor acoplado a proteína G

HEPES- 4-(2-hydroxyethyl)-1-piperazineethanesulfonic acid

HIF1a- Hypoxia-inducible factor 1-alpha - fator indutor de hipóxia 1 alfa

HIF2a- Hypoxia-inducible factor 2-alpha - fator indutor de hipóxia 2 alfa

HMGCoA - 3-hydroxy-3-methyl-glutaryl-Coenzime A reductase - coenzima A 3-

hidroxi-3-metilglutaril

hPheo- Human pheochromocytome

HRE- Hormone response element

IGF-1 - Insulin-like growth factor 1 fator de crescimento 1 semelhante a insulina

IGF1R- Insulin-like growth factor 1 receptor - receptor 1 do fator de cresciemento semelhante a insulina

IGF-BP3- Insulin-like growth factor-binding protein 3 - fator de crescimento ligada a proteína 3 semelhante a insulina

IR- insulin receptor - receptor de insulina

IRS1- Insulin receptor substrate 1 - substrato 1 do receptor de insulina

Kd- kiloDalton - kiloDalton

LKB1- liver kinase B1 - proteína quinase B1 do fígado

MATE- aluminum-activated citrate transporter

MAX- MYC associated fator $X$

MEK- MAP kinse-ERK kinase

Met- metformina

microRNA - micro-ribonucleic acid

MID1- Midline 1

MPC- mouse pheochromocytoma

mTOR- mammalian target of rapamycin - alvo da rapamicina em mamíferos

MTT- 3-(4,5-dimethylthiazole-2-yl)-2,5-diphenyltetrazolium bromide) - brometo de difeniltetrazolium

MTT-Mouse tumor tissue

NADH- Nicotinamide adenine dinucleotide reduced - Dinucleótido de nicotinamida e adenina reduzida

nf1- neurofibromatose 1 gene 
NGF - nerve growth factor

OCT1- organic cation transporter 1

OCTN1- organic cation transporter 1

P53- protein 53- proteína 53

PKA- protein Kinase $A$ - proteína quinase $A$

PMAT- Plasma membrane monoamine transporter

PNMT- feniletanolamina-N-metiltransferase(phenylethanolamine-Nmethyltransferase.

PSA- Prostate-specific antigen - antígeno prostático específico

PTEN- Phosphatase and tensin homolog - fosfatase e homologo de tensina

Raf- fibrosarcoma rapidly accelerated- fibrosarcoma rapidamente acelerado

RagGTPase- enzime Ras-related GTP

RAPTOR- Regulatory-associated protein of $m T O R$ - proteína regulatória associada ao mTOR

PDGFR- Platelet-derived growth factor receptor - receptores de fator de crescimento derivado de plaquetas

$\mathrm{RET}$ - rearranged during transfection protoncogene

RHE- (Ras homolog enriched in brain - proteína homologa do Ras enriquecida do cérebro

S6K- ribosomal protein S6 kinase - proteína ribosomal 6 quinase

SBF- soro bovino fetal

SDS PAGE- Polyacrylamide gel electrophoresis - gel de eletrofose de polecrilamida de dodecil sulfato de sódio

SLC22A- Amphiphilic Solute Transporter branch

Sun- sunitinib

TAK1 - TGF- $\beta$ activated kinase 1 - quinase 1 ativada por TGF- $\beta$

TBST - tampão Tris adicionado Tween 20

TMEM127- transmembrane protein 127 - proteína transmembrana 127

TSC1/ TSC2- tuberous sclerosis 1/ tuberous sclerosis 2

UNICAMP- Universidade Estadual de Campinas

VEGF - vascular endothelial growth factor - fator de crescimento relacionado ao endotélio 


\section{Sumário}

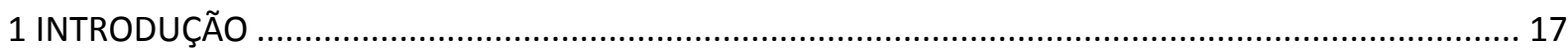

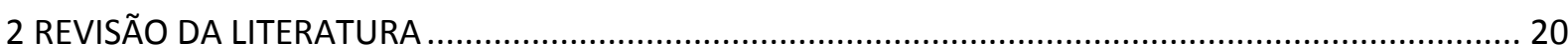

2.1 ADENOCARCINOMA DE PRÓSTATA

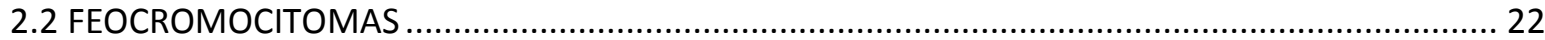

2.3 METFORMINA

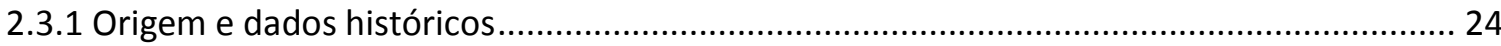

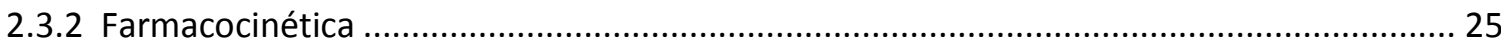

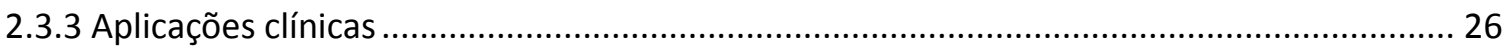

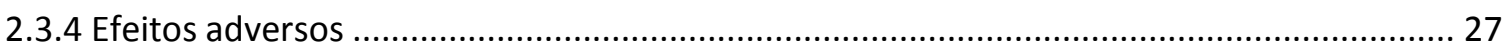

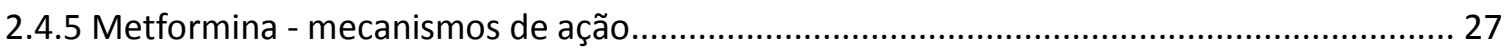

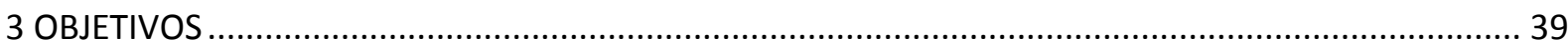

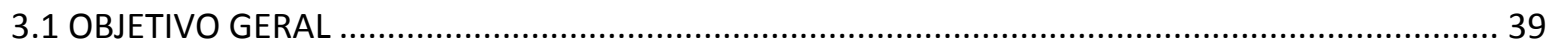

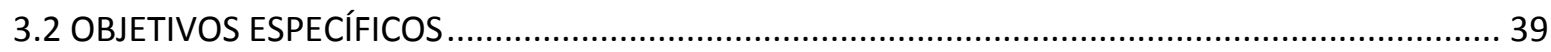

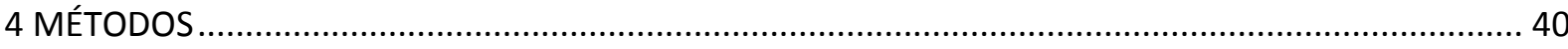

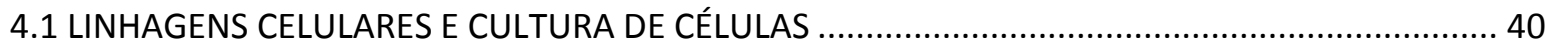

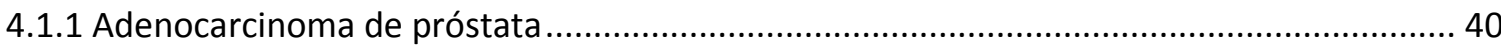

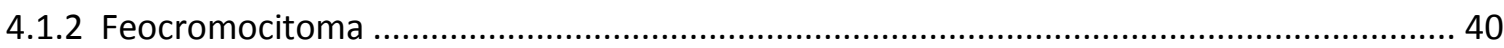

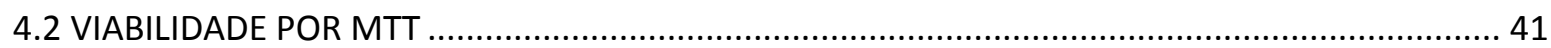

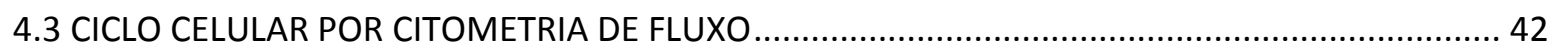

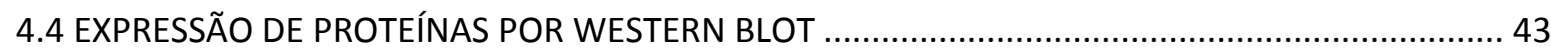

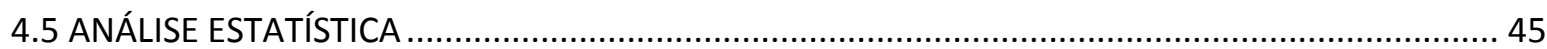

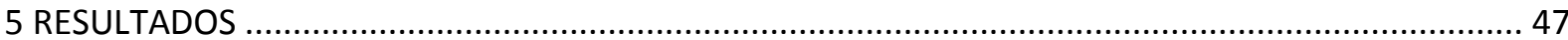

5.1 EFEITO DA METFORMINA SOBRE A VIABILIDADE DE CÉLULAS DE CÂNCER DE PRÓSTATA E DE

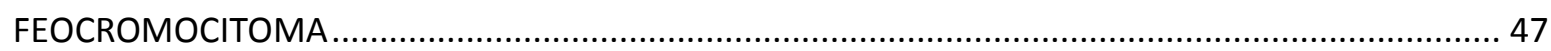

5.1.1 Efeito da metformina sobre a viabilidade das células LNCaP ............................................ 47

5.1.2 Efeito da metformina sobre a viabilidade das células PC3 ................................................ 48

5.1.3 Efeito da metformina sobre a viabilidade das células PC12-Adh.........................................49

Tabela 3: $\mathrm{Cl}_{50}$ e inibição máxima da viabilidade das linhagens celulares de adenocarcinoma de próstata e de feocromocitoma tratadas, utilizando o ensaio MTT.............................................. 50

5.1.4 Efeito da associação de metformina e sunitinib sobre a viabilidade das células PC12-Adh 50

5.2 EFEITO DA METFORMINA NOS EVENTOS DO CICLO CELULAR DAS CÉLULAS PC12-Adh ............ 51 
5.3 EFEITO DA METFORMINA NA EXPRESSÃO DE PROTEÍNAS DA VIA DA APOPTOSE DAS CÉLULAS

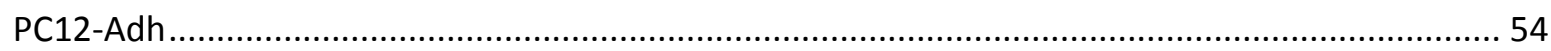

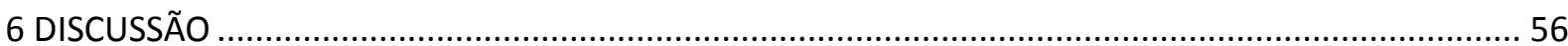

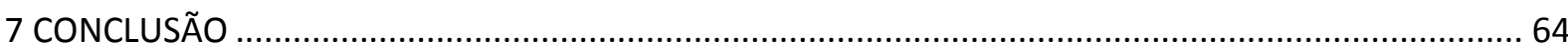

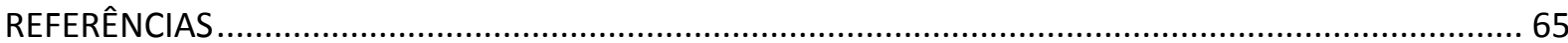




\section{INTRODUÇÃO}

O câncer foi responsável por 8,2 milhões de mortes no mundo no ano de 2012 e estima-se que esse número chegue a 13,2 milhões em 2030. No Brasil, as estimativas são de aproximadamente 576 mil novos casos de câncer no ano de 2015, de acordo com Instituto Nacional do Câncer (1). Trata-se de uma doença complexa, que acomete diferentes órgãos do organismo, com comportamento biológico variável e cuja fisiopatologia está relacionada a fatores endógenos e fatores ambientais. Em comum, sabe-se que o desenvolvimento de câncer decorre de desregulação nos mecanismos de controle da proliferação celular e apoptose. Alterações em genes supressores tumorais, em genes que codificam microRNAs (micro-ribonucleic acid) e em oncogenes têm sido identificados como fatores causais em cânceres, uma vez que podem interferir nesses mecanismos de sobrevivência celular (2).

O adenocarcinoma de próstata é a segunda maior causa de morte relacionada a câncer e a primeira em homens, chegando a 10\% do total de cânceres (1). É um tipo de câncer comum, que está associado a fatores genéticos, dieta hipercalórica, estilo de vida e etnia (3). O feocromocitoma é um tumor neuroendócrino derivado de células cromafins que se encontram na medula da glândula supra-renal. É um tipo de tumor raro, usualmente benigno, porém com elevada morbi-mortalidade. A prevalência do feocromocitoma é de 1:4500 com uma incidência anual de 3 a 8 casos por um milhão na população geral (4). Quando malignos, os feocromocitomas ainda não têm tratamento efetivo e constituem um desafio desde o diagnóstico até seu manejo (5).

A metformina é um fármaco da classe das biguanidas, classificado como antihiperglicemiante oral, utilizado no tratamento do Diabetes Mellitus tipo 2, no qual seu principal efeito é o aumento do consumo da glicose pelo fígado e músculo esquelético (6). O mecanismo de ação envolve alterações metabólicas que afetam a produção de energia da célula e interferem na homeostase. Recentemente foram propostos possíveis mecanismos envolvidos nos efeitos da metformina em alguns tipos de cânceres, como adenocarcinomas de mama (7), pâncreas (8), pulmão (9), intestino (10), próstata (7), mieloma múltiplo (11), dentre outros. O efeito da metformina nesses tipos de cânceres pode estar relacionado a mecanismos 
moleculares que envolvem estimulação de vias compostas por proteínas supressoras tumorais e inibição de vias de proliferação e crescimento celular (12). Entretanto, esses mecanismos encontram-se em investigação inicial e precisam ainda ser melhor elucidados em uma variedade de tumores com comportamento distinto e não justificam, até o momento, o uso clínico da metformina no câncer.

A inserção de fármacos na terapia ou prevenção do câncer, sejam eles novos ou compostos que já apresentem efeito terapêutico específico, requer detalhado entendimento dos efeitos envolvidos, em nível molecular (intracelular), tecidual, farmacocinético e clínico propriamente dito. Idealmente, busca-se identificar fármacos seguros, com baixo risco de efeitos adversos e de baixo custo. Nesse sentido, a busca por efeitos "secundários" ou adjuvantes de medicamentos já amplamente conhecidos e efetivamente utilizados na prática clínica, como a metformina, é racional e interessante.

No que diz respeito ao câncer de próstata, os efeitos in vitro sobre diferentes tipos de células de adenocarcinoma de próstata humanas têm sido bastante explorados nos últimos anos (13-15), porém esses efeitos sobre algumas vias de proliferação ou de supressão tumoral ainda não são completamente compreendidos. Por outro lado, pouco se sabe sobre os mecanismos que determinam o desenvolvimento e comportamento biológico (benigno ou maligno, localização, resposta terapêutica, etc.) de feocromocitomas, e os efeitos da metformina nesses tumores são desconhecidos. Porém, foram descritos efeitos da metformina, in vitro, em linhagens celulares com origem embrionária semelhante aos de feocromocitomas, tais como neuroblastomas, gliomas e ganglioneuroblastomas. Nesses tumores, os quais são também originários de células cromafins, observou-se efeito antiproliferativo, diminuição da progressão do tumor e diminuição da viabilidade celular, quando tratados com metformina $(16,17)$.

Dessa forma, para melhor entendimento acerca da ação da metformina em câncer de próstata e de feocromocitoma faz-se necessário realizar ensaios que contribuam para esclarecer o comportamento das células tumorais na presença da metformina. Considerando a relevância em se esclarecer os efeitos da metformina sobre diferentes tipos de câncer e as possibilidades de sua inserção como parte do 
tratamento, o estudo acerca do comportamento de células de câncer de próstata e de feocromocitoma na presença de metformina foi realizado no presente trabalho. 


\section{REVISÃO DA LITERATURA}

\subsection{ADENOCARCINOMA DE PRÓSTATA}

Adenocarcinoma de próstata é o câncer mais comum em homens e está atrás apenas do câncer de pele não melanoma no Brasil. É o sexto tipo de câncer mais comum no mundo, representando cerca de $10 \%$ do total, com estimativa de 68.800 novos casos em 2015. A taxa de incidência é maior em países desenvolvidos. 0 maior índice ocorre em homens com mais de 65 anos (1).

O rastreamento inicial baseia-se na elevação dos níveis de PSA (Prostatespecific antigen) e exame de toque retal, que é o exame mais específico para detecção do câncer de próstata. Caso ocorra a positivação desses exames, é então indicada a biopsia prostática por ultrasonografia transretal. O prognóstico fundamenta-se na diferenciação histológica de Gleason, que é composta por 5 padrões na escala de graduação. Essa escala varia de 2 a 10, sendo que de 2 a 6 o tumor classifica-se como mais diferenciado ou comportamento menos agressivo, enquanto de 7 a 10 o tumor apresenta comportamento mais agressivo, sendo um tumor menos diferenciado (18).

No caso de tumor localizado, o tratamento pode feito por prostatectomia radical ou radioterapia. Em alguns casos, a doença é considerada incipiente e é apenas recomendado controle clínico, sem necessidade de intervenção cirúrgica ou radioterapia (19). Para pacientes com tumores que evoluem para doença avançada metastática, o tratamento inicial indicado é a supressão androgênica (20).

A terapia de supressão ou deprivação androgênica pode ser realizada de diferentes formas, que incluem desde o uso de análogos de $\mathrm{GnRH}$ (Gonadotropinreleasing hormone), os quais inibem o eixo hipotálamo-hipófise-testículo, até o uso de fármacos antiandrogênicos (21). Dentre estes, a bicalutamida é um antiandrogênico não esteroidal (Figura 1), que se liga a receptores de andrógenos no citosol da célula, inibindo, assim, sua ação. A bicalutamina é, portanto, um antagonista do receptor de andrógenos, que induz diminuição da sinalização 
mediada por mTOR (mammalian target of rapamycin) e inibe a autofagia (renovação das organelas celulares) (22).

A bicalutamida apresenta elevada ligação a proteínas plasmáticas (até 96\%), sofre metabolismo hepático de glicuronidação e oxidação, e é excretada por via renal e fecal. Seus efeitos adversos comuns incluem edema, dor abdominal, constipação, diarreia, náusea, astenia, hematúria, dispneia e dor. Pode ainda apresentar efeitos adversos graves como insuficiência cardíaca congestiva, infarto do miocárdio, hepatotoxiciadade e falência hepática (22).

Estudo realizado por McLeod e colaboradores mostrou que pacientes com câncer de próstata localizado avançado tiveram bom prognóstico quando tratados com bicalutamida (23).

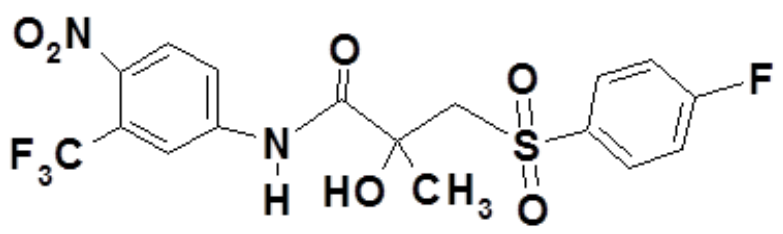

Figura 1: Estrutura da bicalutamida.

A enzalutamida atua também como antiandrogênico, porém interfere na transcrição de proteínas essenciais para autofagia (24). A abiraterona interfere na síntese do hormônio androgênico e, consequentemente, resulta em diminuição da sinalização intracelular dependente da ativação do $\operatorname{AR}$ (androgen receptor) $(25,26)$.

Estudos recentes têm demonstrado diminuição da viabilidade celular de células de adenocarcinoma de próstata humano tratadas com metformina, principalmente em linhagens celulares sensíveis à deprivação androgênica (13). Além de mostrar boa resposta na viabilidade celular desse tipo de célula, foi também observado aumento da apoptose provocado pela metformina em células de câncer de próstata sensíveis a andrógenos e foram descritas algumas vias de sinalização intracelular que poderiam estar envolvidas nesse efeito pró-apoptótico da 
metformina (14). A identificação dessas vias tem se demonstrado essencial para a caracterização de novos alvos terapêuticos intracelulares mais específico.

\subsection{FEOCROMOCITOMAS}

Feocromocitomas são tumores neuroendócrinos raros, derivado de células cromafins localizadas na medula da glândula adrenal. Essas células armazenam, secretam e produzem catecolaminas: epinefrina, noraepinefrina e dopamina $(27,28)$. $\mathrm{Na}$ maioria dos casos, os feocromocitomas originam-se na medula das adrenais e têm comportamento benigno, porém com elevada morbi-mortalidade devido à hipersecreção desregulada de catecolaminas e às emergências cardiovasculares resultantes. Mais raramente, esses tumores são originados das células cromafins dos gânglios do sistema nervoso autônomo que estão presentes em vários órgãos. Nesse caso, sua origem é extra-adrenal, mais frequentemente no tórax, abdome, pelve, cabeça e pescoço, e são chamados paragangliomas (29).

A prevalência de feocromocitoma e paraganglioma é de aproximadamente $0,6 \%$ em pacientes com hipertensão arterial, e até $1,7 \%$ em crianças com hipertensão arterial (5). Sintomas frequentes que ocorrem em portadores de feocromocitoma são: hipertensão, que pode ser paroxística ou não, cefaleia, palpitações e diaforese. A mortalidade nesses pacientes está relacionada com complicações cardiovasculares, principalmente, infarto do miocárdio, acidentes cerebrovasculares (30).

Feocromocitomas e paragangliomas são tumores frequentemente relacionados a fatores hereditários com mutações em genes específicos. Embora ambos tenham origem embriológica semelhante, o comportamento da doença é variável. Enquanto a malignidade ocorre em aproximadamente $10 \%$ dos feocromocitomas, até $40 \%$ dos paragangliomas podem apresentar comportamento maligno e em idade mais precoce, frequentemente na infância (28).

O tratamento é feito com base no comportamento do tumor e visa inicialmente sua retirada cirúrgica e a supressão da secreção endócrina de catecolaminas (29). Não há marcadores diagnósticos de malignidade nesses tumores e somente a evolução e a evidência de recidivas confirma a malignidade, 0 que pode ocorrer muitos anos após a doença inicial. Nos casos malignos, a resposta 
à quimioterapia e radioterapia é muito limitada, e a mortalidade é elevada, mesmo em indivíduos mais jovens (5). Recentemente, novas terapias alvo-dirigidas vêm sendo estudadas, tais como o uso de inibidores de tirosina-quinase (sunitinib, sorafenib), porém seus efeitos ainda são variáveis e parecem depender de outras vias intracelulares envolvidas na tumorigênese (31). Resultados de estudos clínicos preliminares que avaliaram a efetividade do sunitinib tem demonstrado resposta conflitante, porém alguns confirmaram seu efeito antiproliferativo e melhora clínica $(28,32)$.

O sunitinib (Figura 2) é um fármaco antagonista de múltiplos receptores do tipo tirosina-quinase (33) e apresenta efeitos antiangiogênico e antitumoral, agindo principalmente na via VEGFR2/Akt/mTOR/S6K1 (vascular endothelial growth fator receptor 2/ serine/threonine protein kinase Akt/ mammalian target of rapamycin/ ribosomal protein 56 kinase). Essa via de sinalização intracelular está relaciona à síntese de proteínas ribossomais e à proliferação celular (32). Dentre os principais receptores do tipo tirosina-quinase que são inibidos pelo sunitinib, destacam-se os PDGFRs (Platelet-derived growth factor receptors), o c-kit (Stem cell fator) e o VEGF, tanto a isoforma VEGFR-2 quanto a VEGFR-3 $(34,35)$.

O sunitinib já tem sido indicado para o tratamento de alguns tipos de câncer, tais como tumores de pâncreas com origem neuroendócrina (35), tumor de estroma gastrintestinal, carcinoma hepatocelular e leucemias (36).

A farmacocinética do sunitinib envolve ligação a proteínas plasmáticas de 95\%, metabolismo predominantemente hepático pela CYP3A4 (Cytochrome P450 $3 A 4)$, excreção fecal e renal e tempo de meia-vida de 40 a 60 horas (33).

Os efeitos adversos observados com o uso do sunitinib são: vômito, diarreia, astenia e fadiga (37), dor abdominal, constipação, anemia, leucopenia, linfocitopenia, aumento de níveis de acido úrico (33) e hipotireoidismo(38). 


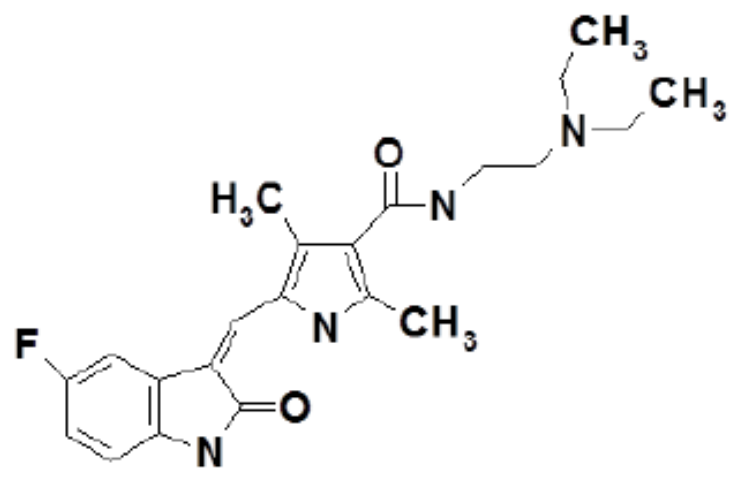

Figura 2: Estrutura do sunitinib.

Assim, embora sejam raros, os feocromocitomas e paragangliomas malignos ainda carecem de tratamento efetivo e representam importante modelo para o estudo dos mecanismos de tumorigênese neuroendócrina e desenvolvimento de novas terapias antineoplásicas alvo-específicas.

\subsection{METFORMINA}

\subsubsection{Origem e dados históricos}

Na Idade Média, a planta francesa Galega officinales era utilizada para aliviar a poliúria, um dos sintomas observados em pacientes com diabetes. Na década 1920, foi isolada a guanidina, obtida do extrato dessa planta. A guanidina é um composto ativo ao qual foram atribuídos os efeitos na melhora dos sintomas de poliúria. A partir da guanidina, foram sintetizadas as guanidas, e a associação delas deu origem a biguanidas. Os primeiros fármacos da classe das biguanidas a serem sintetizados foram fenformina (Figura 3) e buformina (Figura 4) $(7,39,40)$.

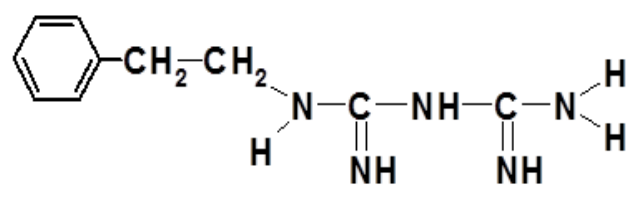

Figura 3: Estrutura da fenformina 
<smiles>CCCCNC(=N)NC=N</smiles>

Figura 4: Estrutura da Buformina

Em 1950, foi aprovada a comercialização desses fármacos na Europa e a partir de então foram registrados graves efeitos adversos ao seu uso, principalmente a acidose láctica. Posteriormente, obteve-se uma molécula com alteração em suas cadeias terminais e inserção de 2 grupos metil, a qual originou a metformina (Figura 5) (39). Entre 1994 e 1995, quando comprovada sua segurança, o FDA (Food and Drug Administration) aprovou seu uso e a metformina começou a ser comercializada nos Estados Unidos. Atualmente a metformina é o fármaco antidiabético oral mais prescrito para o tratamento do diabetes mellitus tipo 2 associado à resistência insulínica (41).

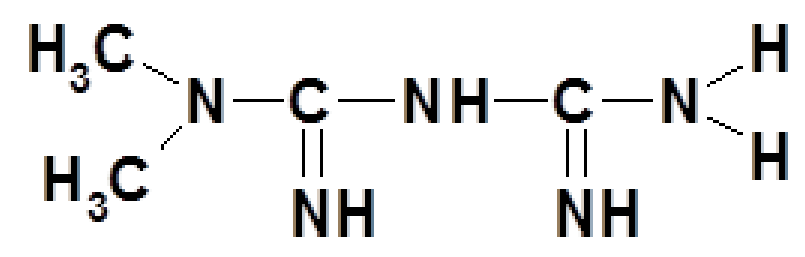

Figura 5: Estrutura da metformina

\subsubsection{Farmacocinética}

A metformina é administrada por via oral com doses variando de $500 \mathrm{mg}$ a $2550 \mathrm{mg} / \mathrm{dia}$ (42). A absorção se dá principalmente no seguimento superior do intestino delgado, chega à circulação portal e acumula-se nos hepatócitos. Este é o seu primeiro sítio de ação, porém não sofre metabolização hepática. A meia-vida varia de 4 a 8 horas e o pico de ação é atingido entre 1,5 a 2 horas (43). Não se liga 
a proteínas plasmáticas, isto é, desloca-se livremente pela circulação e é excretada predominantemente pelos rins por secreção tubular $(43,44)$.

A metformina penetra nas células por meio de um transportador ativo de membrana chamado SLC22A (Amphiphilic Solute Transporter branch). Atua principalmente nas mitocôndrias, onde induz estresse energético celular, um processo que pode estar relacionado com a maioria dos efeitos causados pela metformina. Outros transportadores também foram descritos que podem atuar na entrada de glicose na célula são OCT1, OCTN1(organic cation transporter 1), MATE (aluminum-activated citrate transporter) e PMAT(Plasma membrane monoamine transporter) $(45,46)$.

\subsubsection{Aplicações clínicas}

O uso de metformina aumenta a captação de glicose, mediada por maior sensibilização do receptor de insulina, e aumenta a utilização da glicose pelas células. Entretanto, os mecanismos intracelulares ou teciduais associados a esses efeitos ainda não estão completamente elucidados e têm sido alvo de pesquisas recentes (45). Devido a esses efeitos sistêmicos que favorecem a sensibilização à insulina, a metformina é utilizada em diversas enfermidades além do diabetes mellitus, principalmente aquelas relacionadas à resistência insulínica, diabetes gestacional, síndrome dos ovários policísticos (47), esteatose hepática (44) e síndrome metabólica (48).

Atualmente, é um fármaco frequentemente prescrito nessas situações, com perfil de segurança bastante favorável quando utilizado em doses baixas (49). Há evidências de que o uso de metformina está relacionado a risco diminuído de doenças cardiovasculares e à redução das complicações microvasculares no paciente diabético (50). Outros efeitos atribuídos à metformina são a redução da aterogênese, redução das concentrações plasmáticas de colesterol total e de triglicerídeos, e à redistribuição de adipócitos viscerais (44). 


\subsubsection{Efeitos adversos}

Os efeitos adversos observados com o uso da metformina são principalmente desconforto gastrintestinal, náuseas e diarreia. Acidose láctica é um efeito adverso pouco frequente e é observado em $1 \%$ da população que faz o uso de metformina e em pacientes com disfunção renal $(7,51)$. Em uma revisão da Cochrane 2010, com 347 estudos clínicos, observou-se que o uso da metformina não estava relacionado ao risco de acidose láctica (52). Acidose lática é, portanto, rara, ocorrendo predominantemente em pacientes como hepatopatia, insuficiência renal e abuso do álcool (51). Acidose láctica parece estar relacionada ao efeito inibitório da metformina sobre o complexo 1 da cadeia de transporte de elétrons na mitocôndria e estresse energético intracelular $(41,44)$.

Outro efeito adverso é anemia megaloblástica. O uso crônico de metformina associa-se à deficiência de vitamina $\mathrm{B} 12$, provavelmente devido à diminuição de sua absorção (53).

\subsubsection{Metformina - mecanismos de ação}

2.4.5.1 Mecanismos propostos para os efeitos metabólicos da metformina

Dentre os principais efeitos metabólicos da metformina, e mais recentemente reconhecido, está a inibição da gliconeogênese e efeito antagonista do hormônio alfa pancreático, o glucagon $(54,55)$. O glucagon é liberado em situações de hipoglicemia, age no fígado e promove gliconeogênese e glicogenólise. Em hepatócitos de camundongos, verificou-se que o efeito antagonista do glucagon ocorre como resultado do aumento dos níveis de AMP (adenosine monophosphate) intracelular, que reduz a atividade de enzima adenilato ciclase, a qual, por sua vez, reduz os níveis de CAMP (Cyclic adenosine monophosphate) e inibe a PKA (protein Kinase A). A inibição da PKA impede a fosforilação de alvos críticos intracelulares e o efeito final é o bloqueio da gliconeogênese hepática mediada pelo glucagon e da glicogenólise (54). 
A metformina aumenta a sensibilidade à insulina e resulta na redução dos níveis de glicose plasmática e a estimulação da utilização de glicose pelos músculos. Há evidências de que inibe genes que participam da gliconeogênese (48), e de que a metformina melhora a atividade de tirosina-quinase, que medeia a ativação do receptor de insulina. Consequentemente, ocorre aumento da sinalização celular que favorece a transposição dos canais GLUT1 (Glucose transporter 1), (presente principalmente no fígado) e GLUT 4 (Glucose transporter 4) (transportadores de glicose para dentro da células musculares esquelética) para as membranas celulares, o que resulta em maior captação de glicose sérica $(39,46)$.

A metformina também induz diminuição da lipólise e consequente diminuição de substratos que poderiam ser utilizados para gliconeogênese. O AMPK (adenosine monophosphate-activated protein kinase) ativado, gera diminuição da ativação da HMGCoA redutase (3-hydroxy-3-methyl-glutaryl-Coenzime $A$ reductase), enzima que participa da síntese do colesterol. Ocorre redução dos produtos gerados por essa síntese, sendo que alguns deles são esses essenciais para proliferação e sobrevivência celular (49).

Mais recentemente, observou-se que a metformina inibe o complexo 1 da cadeia de transporte de elétrons, o que gera acúmulo intracelular de $\mathrm{NADH}$ (Nicotinamide adenine dinucleotide reduced). O NADH funciona como sinalizador energético na célula; à medida em que é formado, é utilizado pelo complexo 1 ou $\mathrm{NADH}$ desidrogenase da cadeia de transporte de elétrons, que então oxida NADH em NAD e $\mathrm{H}^{+}$. Essa reação possibilita a formação de energia ao final da fosforilação oxidativa (terceira rota metabólica). Com a inibição do complexo 1 da cadeia de transporte de elétrons, o aumento de NADH sinaliza em direção à interrupção de sua produção a partir das duas primeiras rotas metabólicas para obtenção de energia: a glicólise e ciclo do ácido cíclico. Essa interrupção gera estresse energético. $\mathrm{Na}$ ausência de energia suficiente ou sua diminuição, o piruvato formado ao final da glicólise é desviado para a via do lactato em células hepáticas (55-58).

Diversos outros mecanismos têm sido propostos com base em estudos que avaliaram efeitos pontuais da metformina em diferentes tecidos. Os principais mecanismos estão sumarizados a seguir (55): 
- Retardo na absorção intestinal de glicose e aumento da secreção de GLP-1 (Glucagon-like peptide-1);

- Aumento na produção de lactato pelos enterócitos;

- Ativação da AMPK em hepatócitos, resultante da redução de sua carga energética e da inibição da sinalização induzida pelo glucagon, de enzimas glicolíticas, da transcrição de enzimas gliconeogênicas e do complexo mitocondrial 1.

2.4.5.2 Estudos clínicos e mecanismos propostos para o efeito antineoplásico da metformina

Os efeitos da metformina em alguns tumores começaram a ser observados em séries de pacientes com diabetes mellitus que faziam uso deste medicamento e tinham diagnóstico confirmado de um determinado tipo de tumor. Vários desses estudos observacionais demonstraram redução da progressão do câncer e aumento da sobrevida dos pacientes (7). Dentre os canceres em que foi demonstrada redução de sua progressão ou cura, destacam-se mama, próstata, colo-retal, dentre outros (59-62).

A partir de então, diversos outros estudos verificaram associações entre o uso de antidiabéticos orais e redução da progressão ou incidência do câncer e sugeriram que a metformina seria o antidiabético oral que tinha efeitos sobre a progressão do câncer $(60,61,63-66)$.

Estudo coorte feito por Bowler e colaboradores avaliou a mortalidade por câncer em pacientes que faziam uso de metformina em comparação ao grupo com sulfonilureia, e observou maior mortalidade relacionada ao câncer em pacientes que utilizavam sulfonilureias (67). Em revisão sistemática que incluiu 15 estudos, Singh e colaboradores descreveram efeito protetor da metformina, estatisticamente significativo, sobre a incidência de câncer de colo-retal (66).

Os mecanismos envolvidos em possíveis efeitos antineoplásicos da metformina ainda não foram elucidados, porém têm sido propostos modelos promissores, que apontam para a inibição da proliferação celular e da progressão do 
câncer, estabilização do ciclo celular na fase G0 e estímulo à apoptose. As relações entre metabolismo celular e malignidade têm sido reconhecidas há vários anos $\mathrm{e}$ recentemente têm sido alvo de pesquisas com novos agentes terapêuticos. Tem sido investigado um possível efeito diferencial da metformina sobre vias de sinalização metabólica fisiológica, em células normais, ou sinalização anormal, como ocorre em células neoplásicas, supondo-se um efeito preferencial ou mais específico em células neoplásicas (41).

Em células normais, não neoplásicas, a energia é gerada na forma de ATP (adenosine monophosphate), a partir de três rotas metabólicas principais: a) glicólise; b) ciclo do ácido cítrico; c) cadeia de transporte de elétrons ou cadeia respiratória, seguida de fosforilação oxidativa. Na primeira etapa, ocorre conversão de glicose a piruvato no citoplasma. O piruvato formado nesta via aeróbia, isto é, em condições de elevada disponibilidade de oxigênio, entra na matriz mitocondrial, onde é convertido a Acetil CoA (Acetil coenzime $A$ ). Esse, por sua vez, é utilizado no ciclo do ácido cítrico, onde são produzidos $\mathrm{NADH}, \mathrm{FADH}_{2}$ (Flavin adenine dinucleotide), GDP (Guanosine diphosphate) e ATP $(7,39)$. Resumidamente, as reações da glicólise aeróbia e do ciclo do ácido cítrico resultam principalmente em acúmulo do intermediário $\mathrm{NADH}$, e o desfecho final é a produção de ATP a partir de ADP (adenosine diphosphate) e fosfato, um processo que é definido como fosforilação oxidativa $(15,57)$.

$\mathrm{NADH}$ e FADH2 formados nas primeiras duas rotas metabólicas seguem para a terceira rota metabólica que é a cadeia de transporte de elétrons. Esta é composta por quatro complexos enzimáticos principais: NADH desidrogenase (complexo 1), succinato desidrogenase (complexo 2), ubiquitinol oxidoredutase (complexo 3 ) e citocromo oxidase (complexo 4). O complexo 1 atua juntamente com o complexo $3 \mathrm{e}$ 4 , assim como o complexo $2(7,39)$.

$\mathrm{Na}$ cadeia de transporte de elétrons, as enzimas do complexo 1 oxidam o $\mathrm{NADH}$ formado a partir da glicólise e ciclo do ácido cítrico (2 primeiras rotas metabólicas), gerando NAD, $\mathrm{H}+$ e um elétron para cada molécula de $\mathrm{NADH}$ formada. $\mathrm{O}$ acúmulo de $\mathrm{NADH}$ ativa mecanismos de transporte de elétrons através da membrana interna da mitocôndria, em uma série de reações em cadeia mediadas 
pelas enzimas dos complexos 1, 3 e 4 . O Complexo 2 atua da mesma forma, porém oxida o FADH2, ao invés de NADH, e converte succinato a fumarato (57).

O aumento do gradiente de prótons $\left(\mathrm{H}_{+}\right)$no espaço intermembrana das mitocôndrias, resultante da atividade dos complexos enzimáticos da cadeia respiratória, ativa a enzima ATP sintase que é a responsável final pela fosforilação oxidativa, culminando com a disponibilização de energia à célula (57)

Esses mecanismos de regulação da produção de energia celular encontramse esquematizados na Figura 6.

Nas células neoplásicas, observam-se alterações metabólicas que as distinguem de células não neoplásicas. São células que se proliferam rapidamente e o processo de proliferação celular e crescimento tumoral requer alta energia $(7,39$, 49). Em células neoplásicas, há predomínio das vias da glicólise em detrimento da fosforilação oxidativa. Assim, há aumento da oxidação do piruvato formado e também síntese de ácido láctico, mesmo sob condições aeróbias (com alto aporte de oxigênio). Esse processo é chamado efeito Warburg, tipicamente observado em células com transformação maligna. A gliconeogênese também é aumentada. Um dos mediadores principais desse processo de reprogramação metabólica de alta eficiência no câncer é o HIF-1alfa, um fator de transcrição, ativado por mTORC1 (mammalian target of rapamycin 1), que promove aumento da expressão de enzimas glicolíticas, de transportadores de glicose (GLUT-1) e de MCT4 (monocarboxylate transporter 4), um transportador de ácido láctico nas células. 


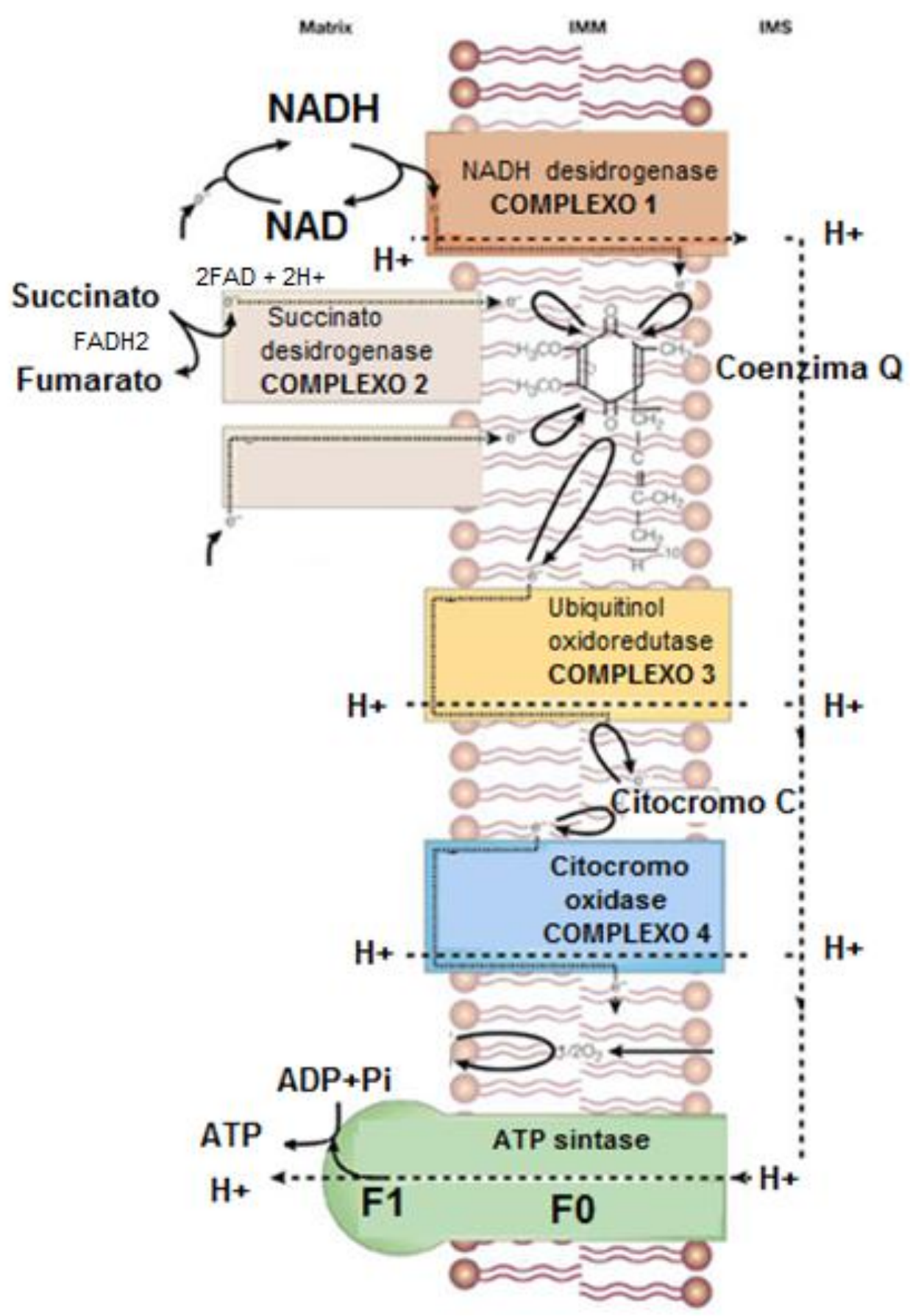

Figura 6: Cadeia de transporte de elétrons e fosforilação oxidativa, figura adaptada (68).

Dentro desse contexto fisiopatológico, onde o desenvolvimento do câncer envolve as alterações características no metabolismo energético da célula neoplásica, os mecanismos propostos para metformina reduzir a sobrevida de 
células de câncer está relacionado basicamente à supressão da energia e consequentemente interrupção ou redução da proliferação celular (49).

\section{Ativação de AMPK e inibição de mTOR como alvos farmacológicos principais}

De maneira semelhante aos seus efeitos metabólicos, a metformina ativa a AMPK, o sensor energético que aumenta em condições de estresse energético celular. Até o momento, tem-se que esses efeitos parecem ser precedidos ou induzidos pela inibição do complexo enzimático 1 da cadeia de transporte de elétrons. Assim, a metformina tenderia a gerar estresse energético, o que, para a célula neoplásica, comprometeria basicamente seus processos de geração de energia $(15,41)$. A inibição do complexo 1 da cadeia de transporte de elétrons parece ser o principal mecanismo de indução de estresse, pois gera diminuição do gradiente de prótons no espaço intermembrana, e consequente diminuição da atividade de ATP sintase. Ocorre diminuição da formação de ATP e aumento dos precursores $\operatorname{AMP}$ e $\operatorname{ADP}(45,69)$. Com o estresse energético gerado pela metformina ao inibir o complexo 1 da cadeia de transporte de elétrons, ocorre o aumento da razão $\operatorname{AMP/ATP}(7,8,41)$. Os níveis aumentados dos precursores AMP e ADP nas células, e redução do ATP, induzem ativação alostérica da AMPK.

A AMPK ativada fosforila outras proteínas que funcionam como supressores tumorais e que diminuem a sinalização de proteínas relacionadas a crescimento e proliferação celular, dentre elas, mTOR $(7,39)$.

mTOR é a subunidade catalítica central de dois complexos proteicos (mTORC1 e mTORC2), os quais têm papel central na promoção do crescimento celular. O mTORC1 está associado ao RAPTOR e apresentam função essencial na síntese proteica que sinaliza para ativação de outras proteínas como S6K (ribosomal protein S6 kinase) e a proteína 4E-BP1, que controla mRNAs. Tem sido relado sinalização positiva do mTORC1 para receptores nucleares que participam da síntese de lipídeos. O mTORC2 está associado ao RIPTOR, porém sua função celular é pouco elucidada. Supostamente o complexo mTROC2 participa da regulação e sobrevivência celular, progressão no ciclo celular e anabolismo (70). 
Quando Rheb (Ras homolog enriched in brain) está bloqueado em virtude da ativação de AMPK pela metformina, ocorre então interrupção na sinalização do mTOR que é uma proteína central que regula outras proteínas ribossomais e crescimento celular (41) (Figura 7).

Além disso, outros complexos proteicos como LKB1 (liver kinase B1), CaMKK2 (calcium/calmodulin-dependent protein kinase kinase 2) e TAK1 (TGF- $\beta$ activated kinase 1) auxiliam na ativação da AMPK, a qual, por sua vez, ativa 0 complexo TSC1/TSC2 (tuberous sclerosis 1/ tuberous sclerosis 2), que funciona como um supressor tumoral. Isso resulta em bloqueio do Rheb, que é um regulador distal do mTOR $(7,8,41)$. AMPK ativada também inibe diretamente a proteína RAPTOR (Regulatory-associated protein of $m T O R$ ), a qual ativa mTOR constitutivamente (7) (Figura 7).

Os efeitos de indução da AMPK e consequente inibição de mTOR constituem os mecanismos dominantes propostos para um efeito direto da metformina sobre as células de câncer (Figura 7). Uma vez ativada, AMPK inibe a neoglicogênese e a síntese proteica, reduzindo a carga energética produzida na célula. Além disso, o aumento de AMPK inibe mTOR, que é uma molécula efetora distal das vias de sinalização de fatores de crescimento celular, comumente ativada em células cancerígenas e associada à resistência a fármacos antineoplásicos (49). Em outras palavras, a supressão de mTOR depende da ativação de AMPK, e esse processo parece representar o efeito antineoplásico mais potente da metormina. A inibição de mTOR afeta a síntese proteica e, consequentemente, a proliferação das células tumorais (71). 


\section{Metformina}
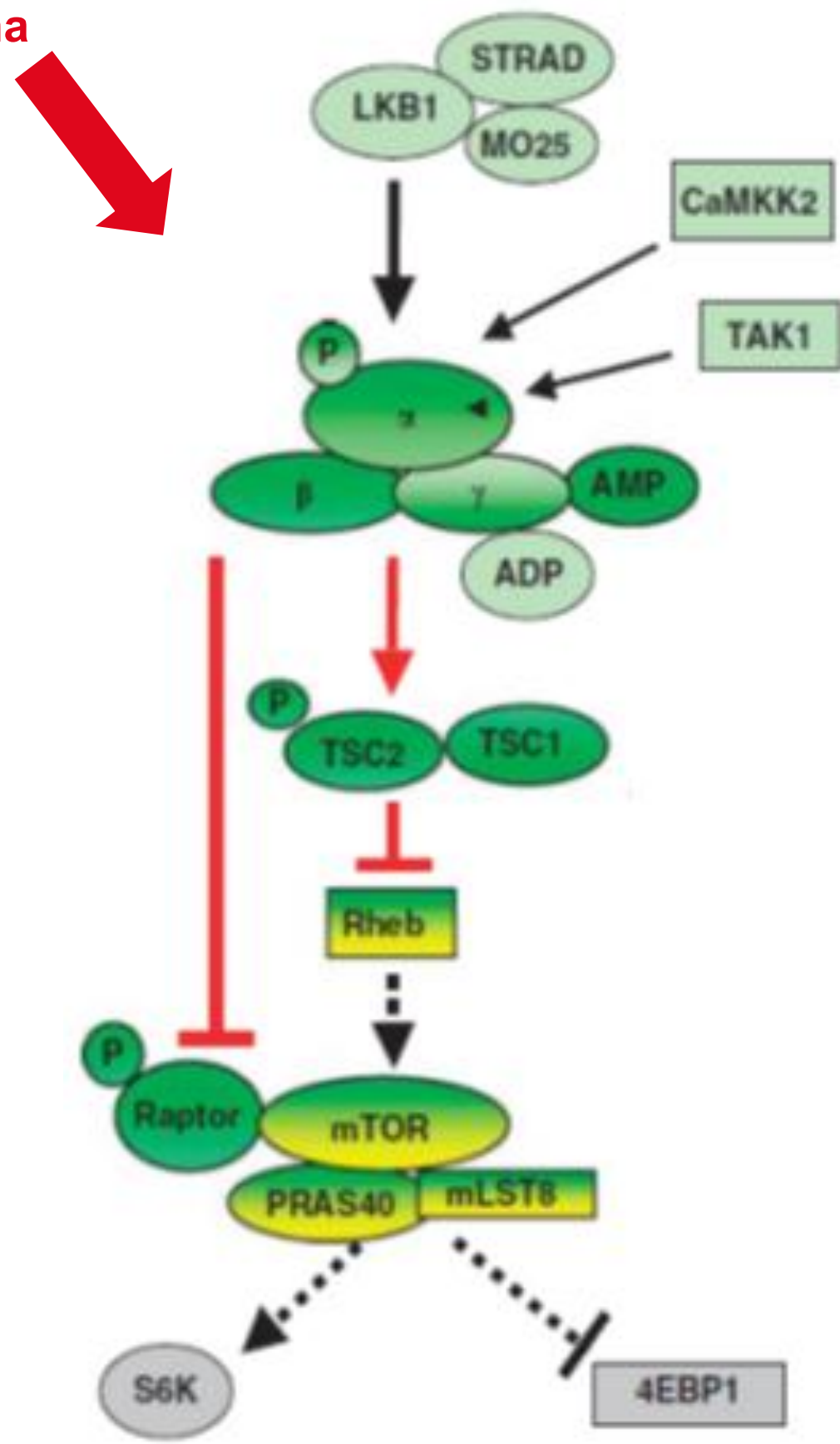

Figura 7: Ativação de AMPK e inibição de mTOR como alvos Farmacológicos principais, figura adaptada (7). 


\section{Inibição da sinalização induzida por fatores de crescimento (insulina e IGF-1) e por receptores acoplados à proteína G (GPCR)}

Adicionalmente, a AMPK ativada inibe IRS-1 (Insulin receptor substrate 1), um mediador da ativação dos receptores de insulina (IR-insulin receptor) e do IGF1R (insulin-like growth factor 1 receptor), que atuam como fatores de crescimento celular. A inibição de IRS-1 resulta em inibição da fosforilação de AKT serine/threonine protein kinase $A k t)$ e, consequentemente, gera diminuição da sinalização do mTORC1 $(7,71)$.

Com a diminuição da sinalização de mTORC1, ocorre regulação negativa (downregulation) de receptores de membrana acoplados à proteína G (GPCR - G protein-coupled receptors) que sinalizam por meio de uma cascata de proteínas de crescimento epitelial Raf/MEK/ERK (fibrosarcoma rapidly accelerated/ MAP kinseERK kinase/extracellular signal-regulated kinases). Assim, a metformina gera diminuição do crescimento celular por inibir a via Raf/MEK/ERK $(7,41)$.

Em conjunto, tem-se que a metformina altera o cross-talk entre as vias de sinalização induzidas por fatores de crescimento, mediadas por IRS-1 e por GPCrs (7). (Figura 8) 


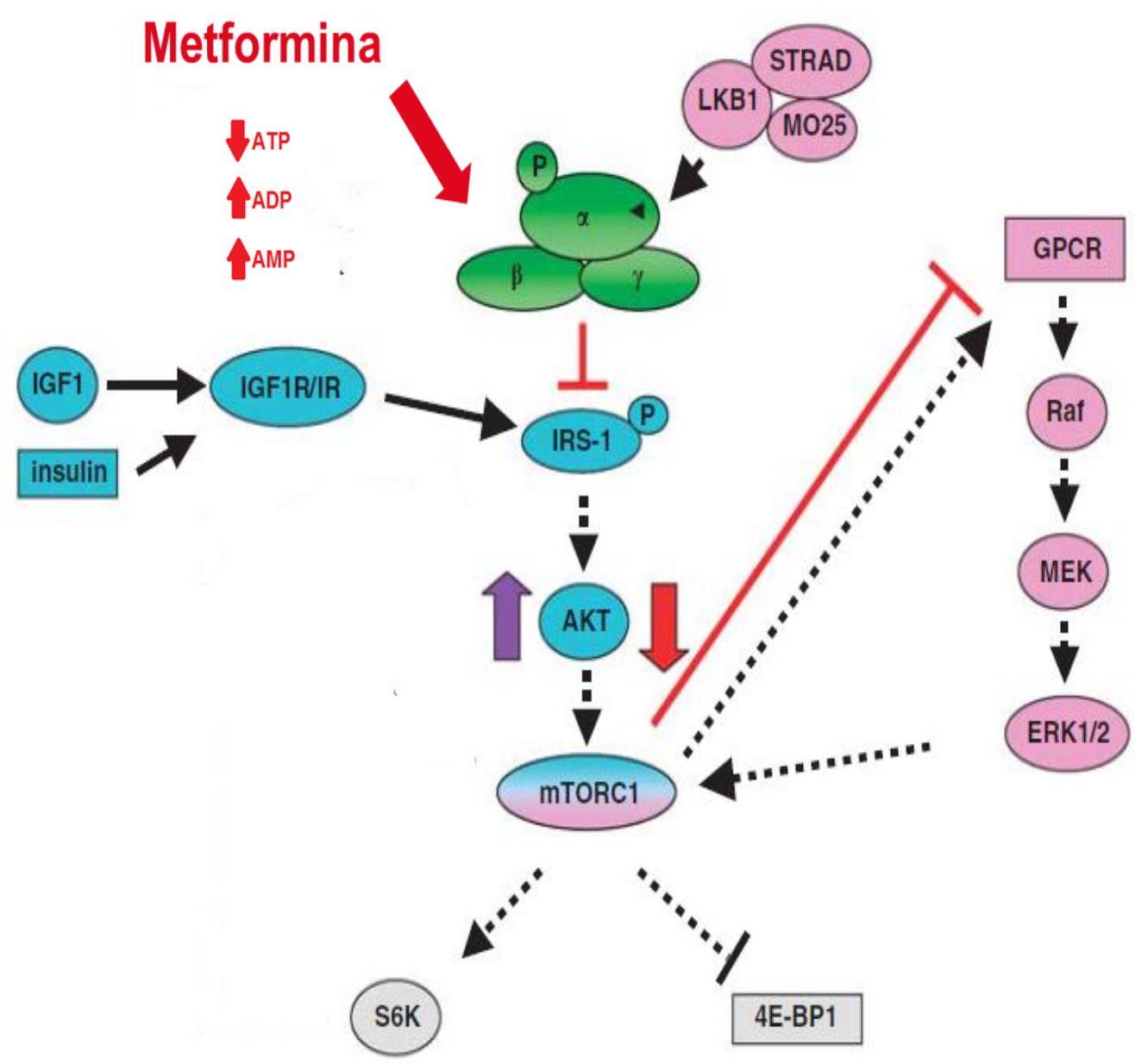

Figura 8: Inibição da sinalização induzida por fatores de crescimento (insulina e IGF-1) e por receptores acoplados à proteína G (GPCR), figura adaptada (7).

\section{Inibição de HIF-1a}

O fator induzivel por hipóxia HIF1a (Hypoxia-inducible factor 1-alpha) é expresso quando a célula entra em estado de hipoxia. Essa proteína é ativada pela proteína ribossomal 70S6K, que é ativado diretamente por mTOR. HIF1a fosforilado (ativado) migra para o núcleo e liga-se à região HRE (Hormone response element) no DNA (Deoxyribonucleic acid), onde ativa a transcrição de vários genes, incluindo VEGF. Em consequência, há aumento da angiogenese (72). 
Tadakawa e colaboradores relatam que na presença de metformina os níveis de HIF1a estão diminuídos, em associação à diminuição da sinalização do mTOR, o que resulta em inibição de VEGF e redução da angiogênese (72). A redução de HIF1a regula negativamente o efeito Warburg observado em células neopásicas, o que contribui para o efeito antineoplásico da metformina (41).

\section{Ativação de p53}

A indução da fosforilação de AMPK pela metormina ativa a proteína supressora tumoral p53 (protein 53), que está envolvida no controle do ciclo celular. p53, por sua vez, ativa vários genes que inibem AKT e mTORC1(8). Contudo, o papel da metformina na ativação de p53 ainda permanece controverso (41).

\section{Inibição de mTOR independente de AMPK}

A inibição de mTOR também é gerada pela metformina por outras vias independentes de AMPK. Por exemplo, a metformina inativa o complexo regulatório RagGTPase (enzime Ras-related GTP), um mediador da ativação de mTORC1 induzida por aminoácidos, independente de $\operatorname{AMPK}(39,41)$. 


\section{OBJETIVOS}

\subsection{OBJETIVO GERAL}

Este estudo tem como principal objetivo investigar o efeito citotóxico da metformina em linhagens celulares de adenocarcinoma de próstata humano e de feocromocitoma de ratos.

\subsection{OBJETIVOS ESPECÍFICOS}

- Investigar a viabilidade de linhagens de células de adenocarcinoma de próstata humano - uma androgênio sensível e outra androgênio resistente - e de feocromocitoma de ratos tratadas com metformina em doses crescentes;

- Investigar o efeito da metformina associada ao sunitinib sobre a viabilidade celular de linhagens de feocromocitoma;

- Investigar o efeito da metformina sobre o ciclo celular de linhagens de células feocromocitoma;

- Identificar o efeito da metformina sobre a expressão de proteínas da via da apoptose de células de feocromocitoma; 


\section{MÉTODOS}

\subsection{LINHAGENS CELULARES E CULTURA DE CÉLULAS}

\subsubsection{Adenocarcinoma de próstata}

Foram utilizadas duas linhagens de células de câncer de próstata, a LNCaP que tem origem de lesão metastática de câncer de próstata humano e se classifica como adenocarcinoma (73). Trata-se de um tipo de células androgênio dependentes que apresenta características semelhantes às células de próstata normal. Outra linhagem de câncer de próstata utilizada nos ensaios foram as células PC3, que também classificam-se como adenocarcinoma e são derivadas de câncer metastático com característica mais resistente (74).

As células LNCaP foram cultivadas em RPMI 1640 (Sigma) suplementado com $10 \%$ de soro fetal bovino (SFB) (Gibco), $1 \%$ de penicilina $100 \mathrm{UI} / \mathrm{mL}+$

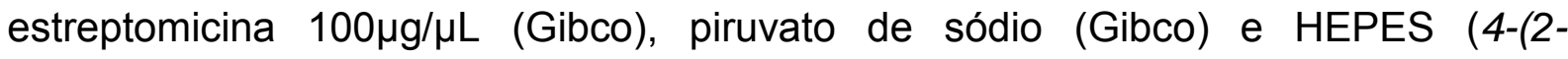
hydroxyethyl)-1-piperazineethanesulfonic acid) (Sigma). As células PC3 foram cultivadas em meio de cultura HAM-F12K (Sigma) suplementado com 10\% de SBF (soro bovino fetal) (Gibco), penicilina $100 \mathrm{Ul} / \mathrm{mL}$ e estreptomicina $(100 \mu \mathrm{g} / \mathrm{mL}$ ) (Gibco). O cultivo celular segue especificações do Banco de células do Rio de Janeiro (BCRJ) do qual foram adquiridas estas células. As células foram mantidas em condições ideais em incubadora com $5 \%$ de $\mathrm{CO}_{2}$ e temperatura de $37^{\circ} \mathrm{C}$.

\subsubsection{Feocromocitoma}

A linhagem PC12-Adh é um tipo de feocromocitoma proveniente de Ratus norvergicus e foi cultivada em meio de cultura HAM-F12 (Sigma) suplementado com $5 \%$ de SBF, $15 \%$ de soro de cavalo (Sigma), penicilina $100 \mathrm{Ul} / \mathrm{mL}$ e estreptomicina $100 \mu \mathrm{g} / \mathrm{mL}$. O cultivo celular segue especificações do Banco de células do Rio de Janeiro (BCRJ) do qual foram adquiridas estas células. As células foram mantidas em condições ideais em incubadora com $5 \%$ de $\mathrm{CO}_{2}$ e temperatura de $37^{\circ} \mathrm{C}$. 
Tabela 1: Características das linhagens celulares.

\begin{tabular}{ccc}
\hline \multicolumn{2}{c}{ Adenocarcinoma de próstata } & Feocromocitoma \\
\hline LNCaP & PC3 & PC12-Adh \\
\hline Homo sapiens & Homo sapiens & Ratus norvergicus \\
Andrógeno & Câncer metastático & Medula adrenal \\
$\begin{array}{c}\text { dependentes } \\
\text { de próstata normal }\end{array}$ & $\begin{array}{c}\text { Resistentes - Menos } \\
\text { diferenciadas }\end{array}$ & $\begin{array}{c}\text { Secretam dopamina e } \\
\text { noraepinefrina } \\
\text { AR positivo }\end{array}$ \\
AR negativo & Não secretam epinefrina \\
\hline
\end{tabular}

\subsection{VIABILIDADE POR MTT}

Para investigar os efeitos da metformina sobre a viabilidade das linhagens LNCaP, PC3 e PC12-Adh foi feito o ensaio de MTT (brometo de 3-(4,5-dimetiliiazol2-il)-2,5-difeniltetrazol) e para avaliar se esse efeito era consideravelmente importante foi feito o mesmo ensaio com bicalutamida nas linhagens LNCaP e PC3 e sunitinib na linhagem PC12-Adh. Após a obtenção dos dados, foi construída uma curva dose resposta para se determinar o $\mathrm{Cl}_{50}(50 \%$ da concentração inibitória máxima) dos tratamentos. Este valor de $\mathrm{Cl}_{50}$ foi utilizado como padrão nos ensaios seguintes.

Células metabolicamente ativas reduzem o MTT a cristais de formazam insolúveis em água e solúveis em etanol. Dessa forma, quanto mais células viáveis, mais cristais são formados e maior será a absorbância da amostra $(75,76)$.

Para realizar o experimento, foram plaqueadas $5 \times 10^{4}$ células por poço em uma placa de 96 poços com volume total de $80 \mu \mathrm{L} /$ poço. Foram incubadas $24 \mathrm{~h}$ para que as células se aderissem à placa e foram adicionados os tratamentos nas concentrações mostradas na Tabela 2. 
Tabela 2: Concentrações dos tratamentos utilizados no ensaio de viabilidade celular com MTT.

\begin{tabular}{cccccc}
\hline \multicolumn{3}{c}{ Metformina $(\mathbf{m M})$} & \multicolumn{2}{c}{ Bicalutamida $(\boldsymbol{\mu M})$} & Sunitinib $(\boldsymbol{\mu M})$ \\
\hline LNCaP & PC3 & PC12-Adh & LNCaP & PC3 & PC12-Adh \\
1 & 1 & 1 & 10 & 10 & 2 \\
5 & 5 & 5 & 20 & 20 & 4 \\
10 & 10 & 10 & 40 & 40 & 5 \\
15 & 15 & 15 & 60 & 60 & 6 \\
20 & 20 & 20 & 80 & 80 & 8 \\
& & 30 & 100 & 100 & 9 \\
& & & & & 10 \\
\hline
\end{tabular}

Os tempos de tratamento realizados foram 24 e 48 horas tanto para a metformina quanto para o maleato de sunitinib (Sigma) e a bicalutamida (Sigma). Após estes tempos, o meio com tratamento foi aspirado e foram adicionados $80 \mu \mathrm{L}$ de meio de cultura específico para cada linhagem celular e $8 \mu \mathrm{L}(10 \%)$ de MTT (Sigma) na concentração de $5 \mathrm{mg} / \mathrm{mL}$ em cada poço e foram incubadas por $4 \mathrm{~h} 37^{\circ}$ $5 \% \mathrm{CO}_{2}$. Em seguida, foram adicionados $80 \mu \mathrm{L}$ de isopropanol acidificado, os cristais formados foram homogeneizados até a dissolução e em seguida foi feita a leitura em espectrofotômetro (Shimadzu) com comprimento de onda de $570 \mathrm{~nm}$. Para a metformina foi feito um controle em um poço contendo células e meio de cultura correspondente a cada linhagem celular e para o sunitinib e bicalutamida foram feitos controles em poços contendo células, meio de cultura para cada linhagem celular e DMSO:EtOH (Dimetilsufoxido:etanol) (2:3), veículo para esses fármacos.

\subsection{CICLO CELULAR POR CITOMETRIA DE FLUXO}

Para avaliar se havia interferência da metformina nas fases do ciclo celular das células PC12-Adh, foi feito um ensaio utilizando a citometria de fluxo laminar, o qual classifica partículas microscópicas suspensas em meio isotônico através de um fluxo luminoso. As células tratadas foram marcadas com iodeto de propídeo que se intercala ao DNA da célula e permite a diferenciação do tamanho do núcleo. O iodeto emite fluorescência que é captada por canais de fluorescência selecionados no citômetro de fluxo. As células foram separadas de acordo com tamanho do 
núcleo, diferenciando cada fase do ciclo celular realizando a contagem em eventos à medida que as células passam pelo fluxo.

Para realizar esse experimento, foram plaqueadas $200 \times 10^{4}$ células/poço em placas de 6 poços. Após 24h, o meio foi aspirado e foi adicionado um novo meio livre de SBF e de soro de cavalo, para que as células sincronizassem-se em uma só fase do ciclo celular (cadenciamento). Após $24 \mathrm{~h}$ o meio foi aspirado e foi adicionado meio com as seguintes concentrações de tratamento: metformina 20,85mM e sunitinib $8,23 \mu \mathrm{M}$. Para a metformina foi feito um controle em um poço contendo células e meio de cultura e para o sunitinib foi feito um controle em poço contendo células, meio de cultura e DMSO:EtOH (2:3).

Os tratamentos foram adicionados e foi aguardado 48h. Após esse tempo, foi adicionado PBS gelado (tampão fosfato salino - meio isotônico), as células foram tratadas com tripsina $0,5 \%$ por 3 minutos, coletadas para um microtubo de centrífuga de $1,5 \mathrm{~mL}$, centrifugadas a 2000rpm por 3 minutos, ressuspensas com $300 \mu \mathrm{L}$ de PBS gelado e foram adicionados $700 \mu \mathrm{L}$ de etanol absoluto para fixação das células na fase do ciclo celular que se encontravam.

Após $24 \mathrm{~h}$ de fixação, as células foram centrifugadas e ressupensas em PBS. Essas células foram marcadas com $50 \mu \mathrm{g} / \mathrm{mL}$ de iodeto de protídeo (intercala ao DNA permitindo a diferenciação pelo tamanho do núcleo) e mantidas no escuro à $4^{\circ} \mathrm{C}$ por pelo menos 1 hora e em seguida foi realizada a leitura em citômetro de fluxo laminar FACSCalibur (BD Biosciences).

A coleta do material e a fixação foram realizadas no Laboratório de Farmacologia Molecular da Universidade de Brasília. A leitura das amostras foi realizada gentilmente pelo biólogo Fábio Haach Téo sob concessão do Professor Dr. Ricardo Coletta no Laboratório de Biologia Celular e Molecular da UNICAMP (Universidade Estadual de Campinas).

\subsection{EXPRESSÃO DE PROTEÍNAS POR WESTERN BLOT}

Para investigar a expressão de proteínas da via da apoptose nas células PC12-Adh foi selecionado o ensaio Western blot utilizando o anticorpo anticaspase 
3 (Santa Cruz) que reconhece proteínas caspase 3 integras (procaspase - massa molecular 33kD) e clivadas (caspase 3 - massa molecular 17kD). Para o controle interno do Western blot foi utilizado o anticorpo anti-GAPDH (Glyceraldehyde 3phosphate dehydrogenase) (Abcam) que reconhece as proteínas GAPDH (37kD), que são proteínas constitutivas das células.

Para obter as proteínas, foram plaqueadas $3 \times 10^{6}$ células em placas de $10 \mathrm{~cm}$, $24 \mathrm{~h}$ depois foi feito o tratamento com a metformina $20,85 \mathrm{mM}$ e sunitinib $8,23 \mu \mathrm{M}$. Para a metformina foi feito um controle em um poço que continha células e meio de cultura e para o sunitinib foi feito controle em um poço que continha células, meio de cultura e DMSO:EtOH (2:3).

Após 48h, o meio de cultura contendo os tratamentos foi aspirado e adicionado PBS, as células foram coletas em microtubo de centrífuga de $1,5 \mathrm{~mL}$ e centrifugadas a $2000 \mathrm{rpm}$ por 5 minutos. Logo a seguir, as células foram ressuspensas com tampão de lise (10\% de sacarose, $1 \%$ NP40, $20 \mathrm{mM}$ de Tris $-\mathrm{pH}$ 8,0,137mM de $\mathrm{NaCl}, 10 \%$ de glicerol, 2mM de EDTA, 10nM de $\mathrm{NaF}$ e inibidor de protease - Roche). As células foram lisadas e centrifugadas novamente a 12000rpm por 20 minutos.

As proteínas foram quantificadas pelos métodos de Lowry (Sigma)(77) e BradFort (Bio-Rad). Uma curva-padrão foi construída com BSA (bovine serum albumin). As absorbâncias encontradas das proteínas foram interpoladas com a curva de BSA, determinando assim a concentração de proteínas totais em cada amostra.

Após a determinação da concentração dessas proteínas, uma amostra foi preparada $(40 \mu \mathrm{g}$ de proteínas + tampão de amostra com betamercaptoetanol e água destilada suficiente para completar $20 \mu \mathrm{L}$ ), as proteínas foram desnaturadas a uma temperatura de aproximadamente $96^{\circ} \mathrm{C}$ por 5 minutos e depois mantidas no gelo por no mínimo 5 minutos, prontas para serem aplicadas em um gel de acrilamida com concentração de $14 \%$. Esse gel foi previamente hidratado com tampão de corrida, submetido a uma corrente de $160 \mathrm{~V}$ por 15 minutos. Em seguidas, foram aplicados $20 \mu \mathrm{L}$ de amostra em cada poço e foi submetido a uma corrente de $110 \mathrm{~V}$ por aproximadamente 2 horas. 
Após a corrida o gel de acrilamida, as proteínas foram transferidas para uma membrana de nitrocelulose, previamente ativada com metanol. Essa transferência ocorreu após a submissão a uma corrente de $24 \mathrm{~V}$ por 1 hora e 30 minutos. Nesse processo, as proteínas que estão separadas no gel por peso molecular, passam então para membrana. Essa membrana foi submetida a bloqueio, com solução bloqueadora $10 \%$ (albumina do leite) por $12 \mathrm{~h}$. Após este tempo, a membrana foi lavada com tampão Tris-salina (0,2 M) e 0,1\% de Tween 20 (TBST) e foi incubada com anticorpo primário anticaspase 3 em uma concentração de 1:500 por 2 horas e em seguida, foi incubada com anticorpo secundário anti-rabbit (o anticorpo primário utilizado é rabbit) (Santa Cruz) em uma concentração 1:5000 por 1 hora. Foi aplicado ECLPRIME (GE) por 5 minutos (esse reagente contém o substrato para enzima ligada ao anticorpo secundário). Os filmes foram expostos em tempos que variavam de instantâneo a 30 minutos e revelados. Essa mesma membrana foi lavada com tampão de stripping - glicina, SDS, Tween 20 - (para retirar os anticorpos) e reencubada com anticorpo primário anti-GAPDH com concentração de 1:1000 (por 2 horas) e o anticorpo secundário anti-goat (o anticorpo primário é goat) com concentração 1:6000 (por 1 hora). Foi aplicado o ECLPRIME e revelado. A quantificação das bandas do western Blot foi feita utilizando o software imageJ®.

\subsection{ANÁLISE ESTATÍSTICA}

Os valores das absorbâncias encontrados no ensaio de viabilidade celular foram plotados no Microsoft Excel 2010 e foi encontrada a porcentagem de células viáveis. A análise estatística selecionada foi regressão não linear com variável slope da dose de inibição versus resposta e cálculo do $\mathrm{Cl}_{50}$. Para a análise dos dados da associação de fármaco foi selecionada a regressão linear. Esses dados foram plotados no GraphPadPrism® versão 5.0 para Windows.

As porcentagens encontradas nos histogramas do ciclo celular foram plotadas no GraphPadPrism ${ }^{\circledR}$ versão 5.0 usando a análise de variância TWO-way ANOVA com padrão de comparação pós-teste Bonferroni.

A quantificação das bandas do Western blot gerou valores de proteína líquida e obteve-se a razão dividindo o tratado pelo controle. Os valores encontrados foram 
plotados no GraphPadPrism® versão 5.0 usando a análise de variância One-way ANOVA com padrão de comparação pós-teste Tukey. 


\section{RESULTADOS}

\subsection{EFEITO DA METFORMINA SOBRE A VIABILIDADE DE CÉLULAS DE CÂNCER DE PRÓSTATA E DE FEOCROMOCITOMA}

\subsubsection{Efeito da metformina sobre a viabilidade das células LNCaP}

Foi feito um padrão utilizando bicalutamida, um fármaco que sabidamente exerce efeito sobre a viabilidade das células $\mathrm{LNCaP}$, atuando como antagonista do receptor de andrógeno, para validar o ensaio, um fármaco. A Figura 9A mostra a redução da viabilidade em $55 \%$ no tratamento das células $\mathrm{LNCaP}$ com bicalutamida por $48 \mathrm{~h}$.

O efeito da metformina sobre a viabilidade das células $L N C a P$ nos períodos de 24 e 48h pode ser visto na Figura 9B. Com o aumento da concentração da metformina a viabilidade celular foi decaindo, pode-se inferir que o efeito da metformina nas células LNCaP é dose e tempo dependente e o valor do $\mathrm{Cl}_{50}$ encontrado foi igual a $7,96 \mathrm{mM}$ em $24 \mathrm{~h}$ e $7,89 \mathrm{mM}$ em $48 \mathrm{~h}$ (Tabela 3).
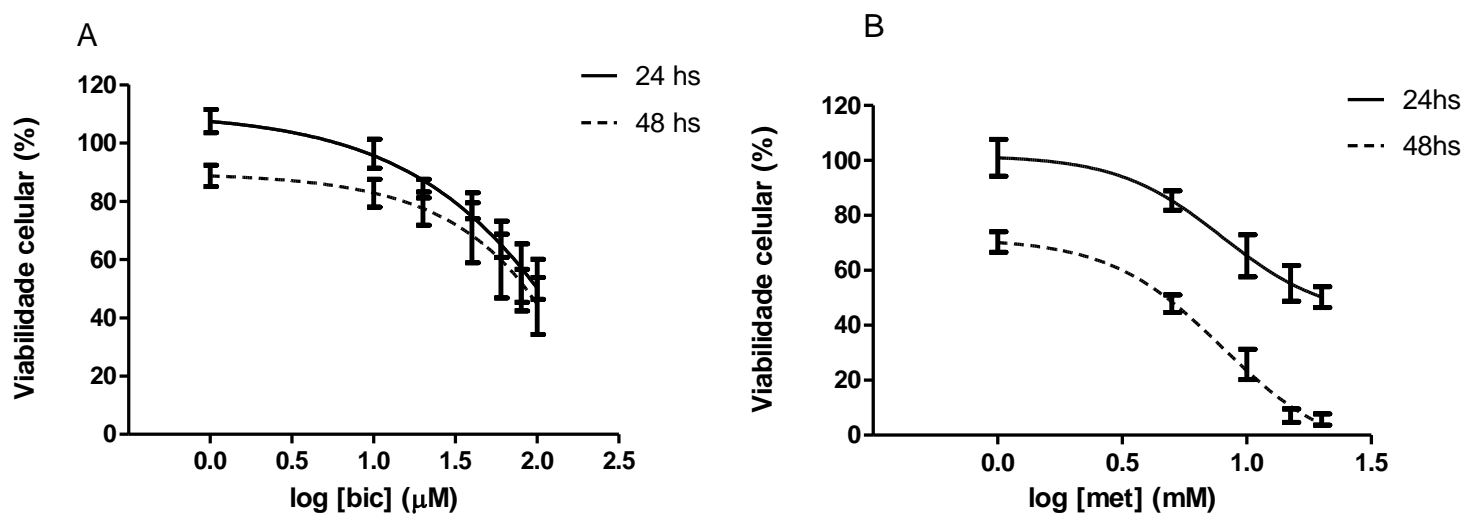

Figura 9: Ensaio de viabilidade celular por MTT. A - Células LNCaP tratadas com bicalutamida (bic)

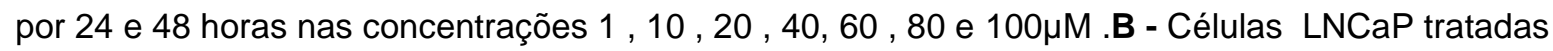
com metformina (met) por 24 e 48 horas nas concentrações 1, 5, 10, 15 e $20 \mathrm{mM}$ usando o ensaio de MTT. Os pontos no gráfico representam a média+EPM de 3 experimentos independentes em triplicata. 


\subsubsection{Efeito da metformina sobre a viabilidade das células PC3}

A metformina reduz a viabilidade das células $\mathrm{LNCaP}$, uma linhagem sensível que expressa AR (androgen receptor). Para investigar a possibilidade desse efeito sobre a viabilidade estar relacionado ao receptor de androgênios, optou-se por realizar o mesmo ensaio com uma célula que não expressa esse receptor. As células PC3 foram tratadas com bicalutamida, para padronização do ensaio e foi observada uma redução na viabilidade de $40 \%$ e inibição de $20 \%$ quando as células foram tratadas com metformina por $48 \mathrm{~h}$ com $\mathrm{Cl}_{50}=19,2 \mathrm{mM}$ (Figura 10 e Tabela 3).

A
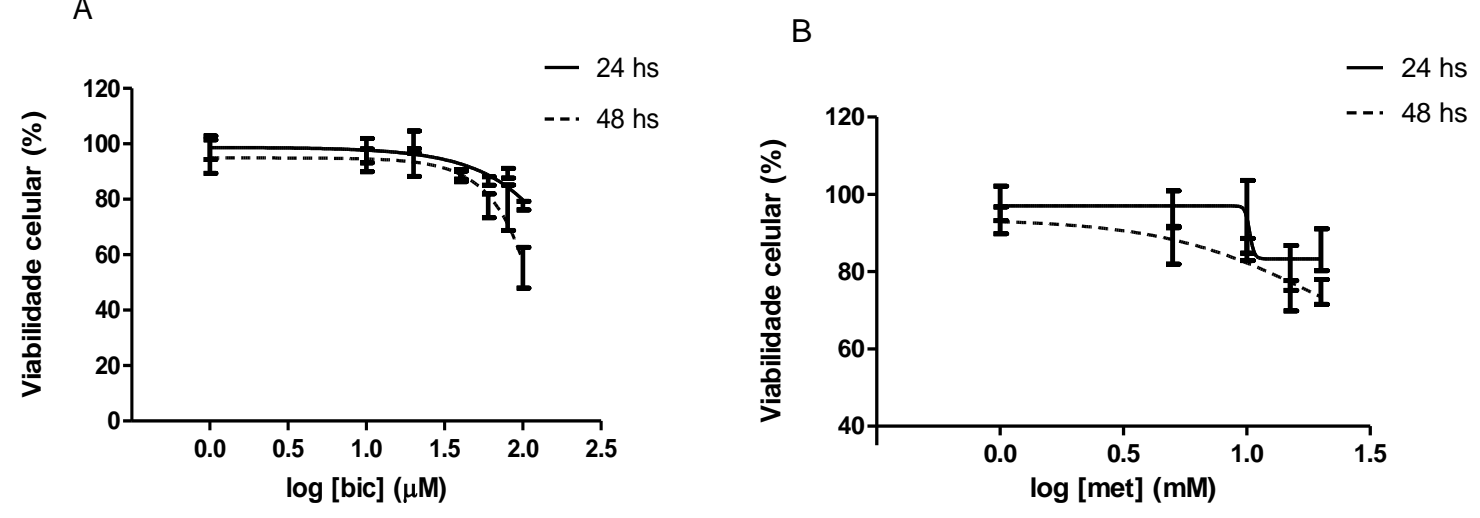

Figura 10: Ensaio de viabilidade celular por MTT. A- Células PC3 tratadas com bicalutamida (bic) por

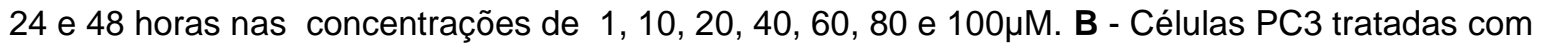
metformina (met) por 24 e 48 horas nas concentrações de 1, 5, 10, 15 e 20mM. Os pontos no gráfico representam a média \pm EPM de 3 experimentos independentes em triplicata. 


\subsubsection{Efeito da metformina sobre a viabilidade das células PC12-Adh}

Os efeitos da metformina na linhagem celular de feocromocitoma - PC12-Adh, não estão descritos, dessa forma, foi realizado um ensaio de viabilidade usando MTT e para padronização do ensaio foi utilizado o sunitinib, um inibidor de tirosinaquinase que sabidamente exerce efeito sobre a linhagem PC12-Adh(32). O resultado mostrou uma redução da viabilidade celular em aproximadamente 55\% com $\mathrm{Cl}_{50}=8,23 \mu \mathrm{M}$ com tratamento feito em 48h (Figura 11A). O tratamento com metformina mostrou uma redução da viabilidade celular em $40 \%$ das células em tratamento feito por 48h com 20,85Mm (Figura 11B). A Figura 11C mostra redução número de células PC12-Adh com tratamento com sunitinib $8,23 \mu \mathrm{M}$ por $48 \mathrm{~h}$ e alteração da morfologia das células e redução do número de células tratadas com metformina 20,85 mM por 48 horas comparando com controle (Tabela 3).

A

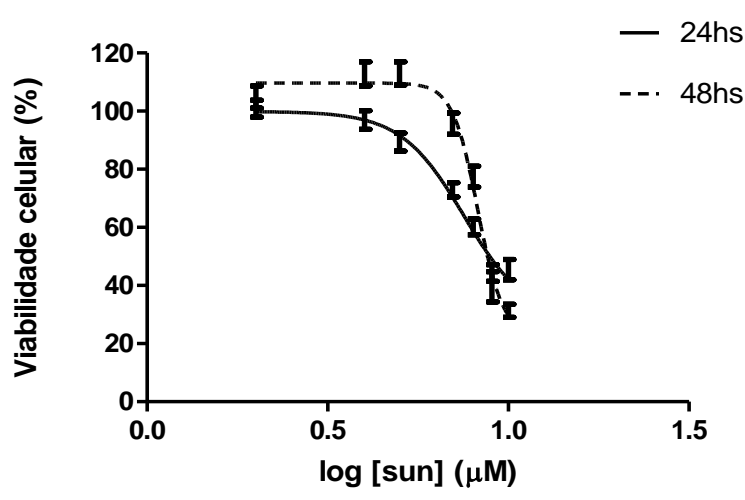

C-1

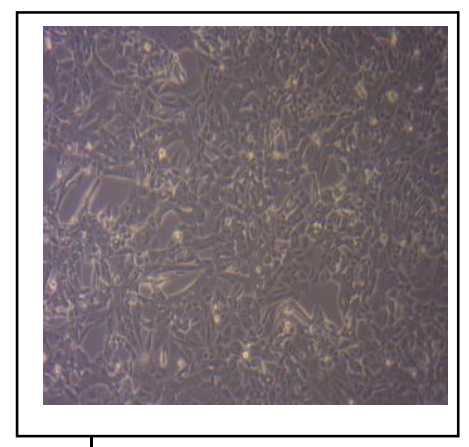

C-2

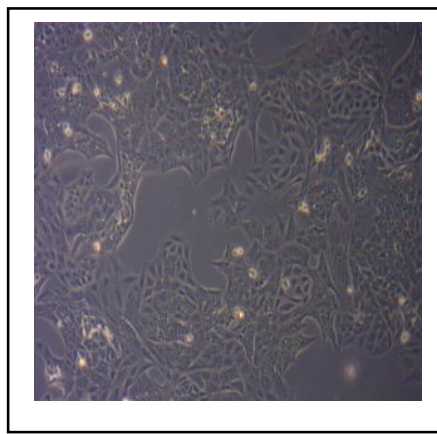

B

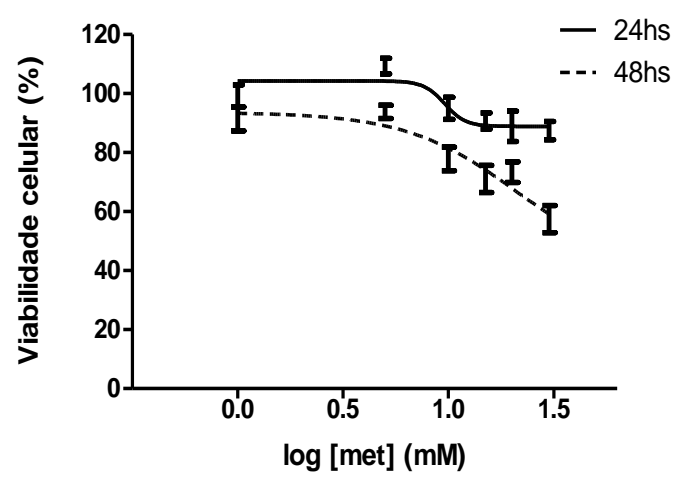

C-3

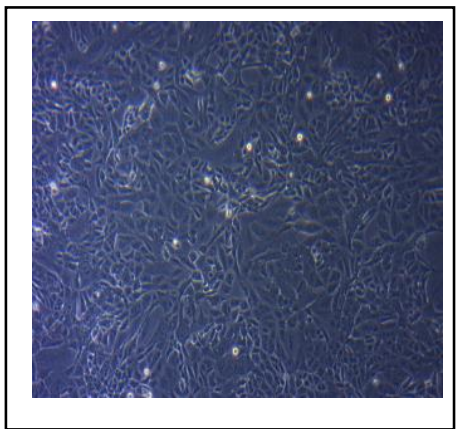

C-4

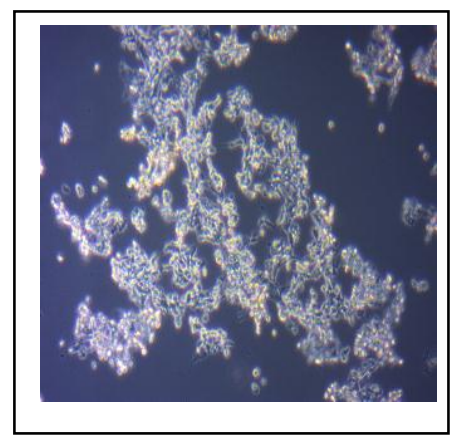

Figura 11: Ensaio de viabilidade celular por MTT. A- Células PC12-Adh tratadas com sunitibib (sun) por 24 e 48h nas concentrações 2, 4, 5, 7, 8, 9 e 10 $\mu \mathrm{M}$. B - Células PC12-Adh tratadas com metformina (met) por 24 e 48h nas concentrações 1, 5, 10, 15, 20 e $30 \mathrm{mM}$. Os pontos no gráfico representam a média+EPM de 3 experimentos independente em triplicata. C- Células PC12-Adh visualizada no aumento de 20X. C-1 controle DMSO:EtOH 2:3 + meio de cultura; C-2 tratamento com sunitinib na concentração $8.23 \mu \mathrm{M}$ por $48 \mathrm{~h}$; C-3 controle (meio de cultura); C-4 tratamento com metformina $20.85 \mathrm{mM}$ por $48 \mathrm{~h}$; Imagens da autora. 
Tabela 3: $\mathrm{Cl}_{50}$ e inibição máxima da viabilidade das linhagens celulares de adenocarcinoma de próstata e de feocromocitoma tratadas, utilizando o ensaio MTT.

\begin{tabular}{cccccc}
\hline & $\begin{array}{c}\text { Linhagem } \\
\text { celular }\end{array}$ & $\mathbf{C l}_{\mathbf{5 0}} \mathbf{2 4 H s}$ & $\begin{array}{c}\text { Inibição } \\
\text { máxima da } \\
\text { viabilidade(\%) }\end{array}$ & $\mathbf{C l}_{\mathbf{5 0}} \mathbf{4 8 H s}$ & $\begin{array}{c}\text { Inibição } \\
\text { máxima da } \\
\text { viabilidade(\%) }\end{array}$ \\
\hline Metformina & LNCaP & $7,96 \mathrm{mM}$ & $50 \%$ & $7,89 \mathrm{mM}$ & $97 \%$ \\
Bicalutamida & LNCaP & - & $50 \%$ & - & $50 \%$ \\
Metformina & PC3 & $10,28 \mathrm{mM}$ & $10 \%$ & $19 \mathrm{mM}$ & $20 \%$ \\
Bicalutamida & PC3 & - & $20 \%$ & - & $40 \%$ \\
Metformina & PC12-Adh & $9,59 \mathrm{mM}$ & $10 \%$ & $20,85 \mathrm{mM}$ & $40 \%$ \\
Sunitinib & PC12-Adh & $7,53 \mu \mathrm{M}$ & $60 \%$ & $8,23 \mu \mathrm{M}$ & $65 \%$ \\
\hline
\end{tabular}

\subsubsection{Efeito da associação de metformina e sunitinib sobre a viabilidade das células PC12-Adh}

A metformina e o sunitinib inibem a viabilidade das células PC12-Adh e esse efeito é mais evidente no tratamento de $48 \mathrm{~h}$. Com o intuito de potencializar o efeito de inibição da viabilidade celular do sunitinib, foi associada a metformina (concentrações entre 1 e $30 \mathrm{mM})$ com uma concentração fixa do sunitinib $(8,23 \mu \mathrm{M}$ concentração esta igual à $\mathrm{Cl}_{50}$ obtida no ensaio de viabilidade celular com MTT), mostrando redução da viabilidade em aproximadamente $35 \%$ com $\mathrm{Cl}_{50}=12,57 \mathrm{mM}$ em 24h e $\mathrm{Cl}_{50}=13,78 \mathrm{mM}$ em $48 \mathrm{~h}$ como pode ser observado na Figura 12A.

A ação do sunitinib sozinho na concentração de $8,23 \mu \mathrm{M}$ nas células $\mathrm{PC} 12$ reduziu a viabilidade das células para $67 \%$. Ao adicionar-se metformina nas concentrações de 1 a $30 \mathrm{mM}$ houve uma redução da inibição da viabilidade celular, ou seja, a viabilidade celular foi para aproximadamente $90 \%$. O aumento da concentração de metformina provocou uma diminuição da viabilidade celular até atingir 70\% e 55\% (em 24 e 48h, respectivamente) na concentração mais alta do ensaio que foi $30 \mathrm{mM}$. Pensando no efeito protetor da metformina na ação do sunitinib, foi construída uma curva aumentando a concentração do sunitinib para $20 \mu \mathrm{M}$ e mantendo as concentrações da metformina variando entre $1 \mathrm{a} 30 \mathrm{mM}$ e foi observado que esse efeito de proteção permanecia. A viabilidade das células usando somente sunitinib chega a $43 \%$, quando é adicionada a metformina, nas primeiras doses observa-se um reestabelecimento da viabilidade para $80 \%$ e a 
medida que aumentam as doses da metformina, a viabilidade reduz para $48 \%$ em 24 e 48h (Figura 12 e Tabela 4).

A

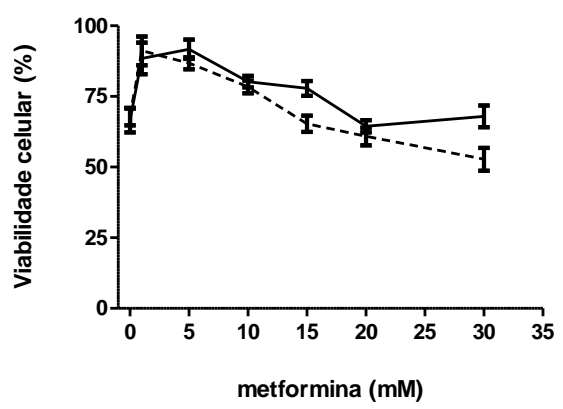

B

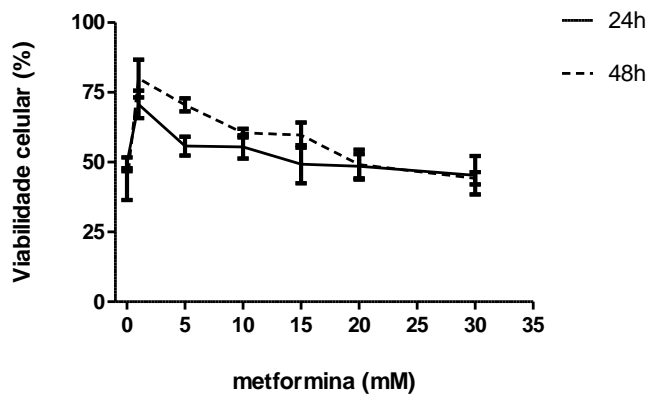

Figura 12: Efeito da associação de metformina e sunitinib sobre a viabilidade das células PC12-Adh. Ensaio de viabilidade celular por MTT. A - Concentração constante de sunitinib $8,23 \mu \mathrm{M}$ e concentrações crescentes de metformina $1,5,10,15,20$ e $30 \mathrm{mM}$ por 24 e 48 horas. B-

Concentração constante de sunitinib $20 \mu \mathrm{M}$ e concentrações crescentes de metformina 1, 5, 10, 15, 20 e $30 \mathrm{mM}$ por 24 e 48 horas. Os pontos no gráfico representam a média土EPM de 3 experimentos independentes em triplicata.

Tabela 4: Associação de metformina em concentrações crescentes e sunitinib em concentrações fixas $8,23 \mu \mathrm{M}$ e $20 \mu \mathrm{M}$ em 24 e 48 horas.

\section{Viabilidade celular}

\begin{tabular}{|c|c|c|c|c|}
\hline Metformina & $\begin{array}{c}\text { Sunitinib } 8,23 \mu \mathrm{M} \\
24 \mathrm{hs}\end{array}$ & $\begin{array}{c}\text { Sunitinib } 8,23 \mu \mathrm{M} \\
48 \mathrm{hs}\end{array}$ & $\begin{array}{c}\text { Sunitinib } 20 \mu \mathrm{M} \\
24 \mathrm{hs}\end{array}$ & $\begin{array}{c}\text { Sunitinib } 20 \mu \mathrm{M} \\
48 \mathrm{hs}\end{array}$ \\
\hline 0 & $67 \%$ & $67 \%$ & $50 \%$ & $43 \%$ \\
\hline $1 \mathrm{mM}$ & $88 \%$ & $90 \%$ & $70 \%$ & $80 \%$ \\
\hline $5 \mathrm{mM}$ & $91 \%$ & $87 \%$ & $55 \%$ & $70 \%$ \\
\hline $10 \mathrm{mM}$ & $80 \%$ & $80 \%$ & $55 \%$ & $60 \%$ \\
\hline $15 \mathrm{mM}$ & $77 \%$ & $65 \%$ & $50 \%$ & $60 \%$ \\
\hline $20 \mathrm{mM}$ & $65 \%$ & $60 \%$ & $50 \%$ & $50 \%$ \\
\hline $30 \mathrm{mM}$ & $70 \%$ & $55 \%$ & $48 \%$ & $48 \%$ \\
\hline
\end{tabular}

\subsection{EFEITO DA METFORMINA NOS EVENTOS DO CICLO CELULAR DAS CÉLULAS PC12-Adh}


Inicialmente foi avaliado o efeito do sunitinib sobre as células PC12-Adh para estabelecer um padrão e foi utilizado na concentração de $8.23 \mu \mathrm{M}$ por $48 \mathrm{~h}$. Não houve alteração nos eventos do ciclo celular, como mostra a Figura 13.

A1

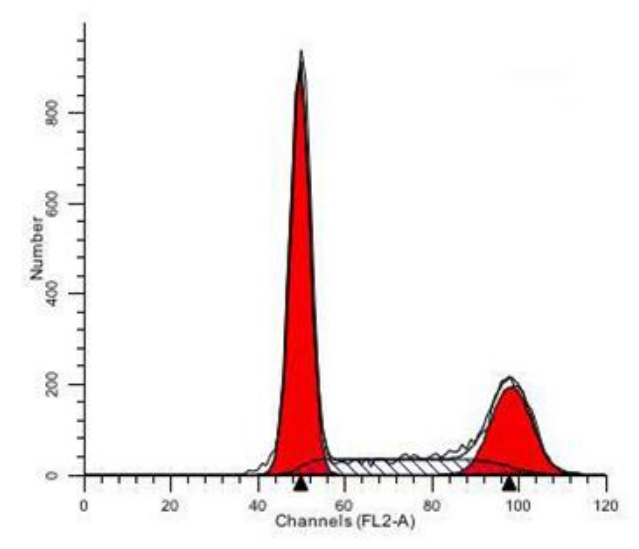

A2

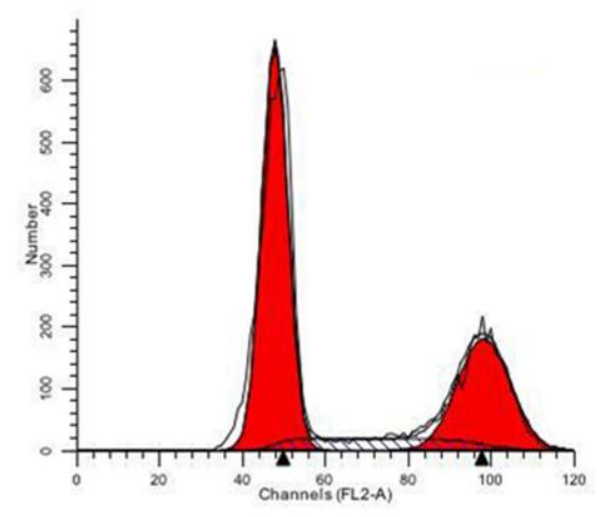

B

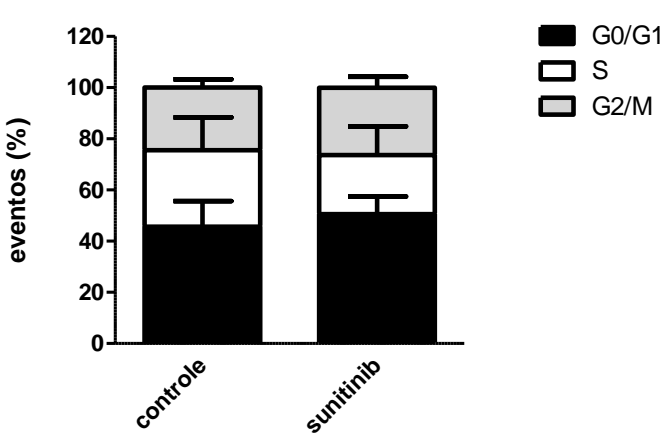

Figura 13: Ensaio da avaliação do ciclo celular em citômetro de fluxo. Ciclo celular de células PC12Adh tratadas com sunitinib $8.23 \mu \mathrm{M}$ por $48 \mathrm{~h}$. A - Imagem representativa da distribuição dos eventos marcados com iodeto de propídeo no histograma: fase G0/G1 - 1o pico em vermelho, fase G2/M - 20 pico em - fase S - vermelho e região tracejada. A1 - controle (meio de cultura + DMSO:EtOH 2:3); A2 - sunitinib $(8,23 \mu \mathrm{M})$. B - Representação de 3 experimentos independentes dos eventos por fase do ciclo celular.

A metformina reduz a viabilidade de células PC12-Adh como visto na Figura 11B. Com base nos dados obtidos no ensaio de viabilidade das células PC12-Adh tratadas com metformina optou-se em realizar um ensaio que avaliasse o efeito da 
metformina 20,85 mM nos eventos do ciclo celular. Os dados da Figura 14 mostram que não houve aumento da quantidade de células PC12-Adh na fase do ciclo G0/G1 quando tratadas, dessa forma, metformina não altera o ciclo celular das células PC12-Adh com tratamento feito em $48 \mathrm{~h}$.

A1

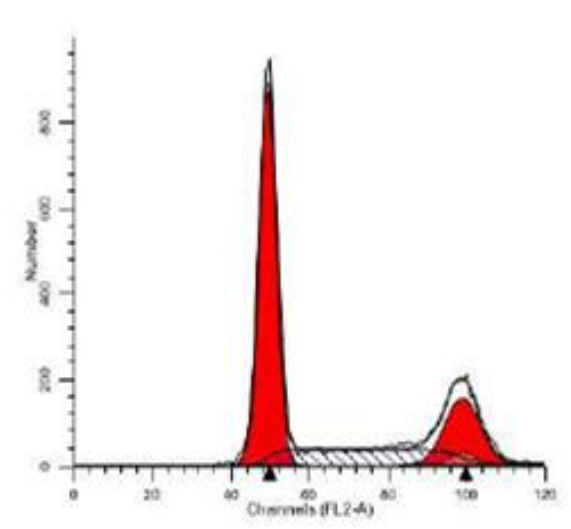

A2

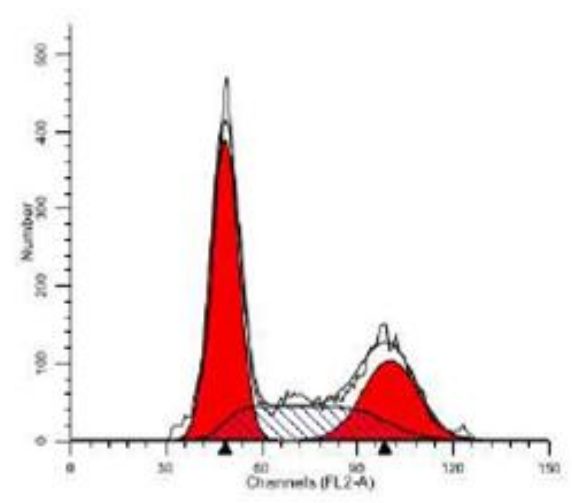

B

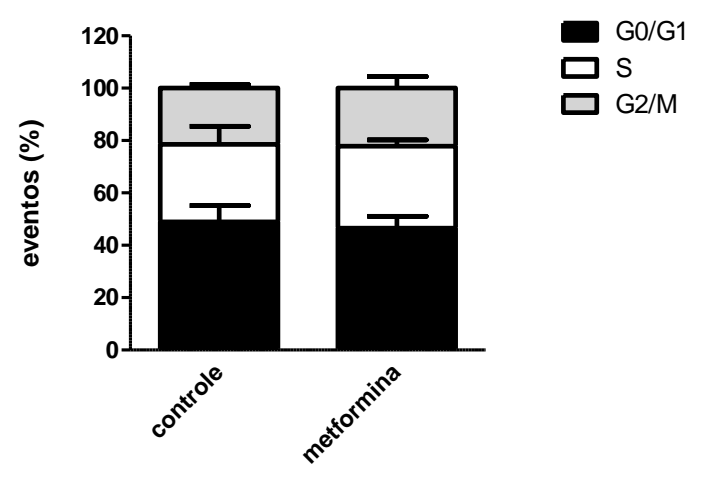

Figura 14: Ensaio de avaliação do ciclo celular em citômetro de fluxo. Ciclo celular de células PC12Adh tratadas com metformina $20.85 \mathrm{mM}$ por $48 \mathrm{~h}$.. A - Imagem representativa da distribuição dos eventos e marcação das células com iodeto de propídeo no histograma: fase G0/G1 - 10 pico em vermelho, fase $\mathrm{G} 2 / \mathrm{M}-2^{\circ}$ pico em vermelho - fase S - e região tracejada. A1 - controle (meio de cultura); A2 - metformina (20,85mM ). B - Representação de 3 experimentos independentes dos eventos por fase do ciclo celular. 


\subsection{EFEITO DA METFORMINA NA EXPRESSÃO DE PROTEÍNAS DA VIA DA APOPTOSE DAS CÉLULAS PC12-Adh}

Para identificar o efeito da metformina sobre a expressão de proteínas da via da apoptose, caspase 3, inicilamente foi estabelecido um padrão utilizando sunitinib $8,23 \mu \mathrm{M}$ por 48 horas em células PC12-Adh como pode ser visto na Figura 15 que mostrou aumento da expressão de caspase 3 clivada e redução da expressão de pró-caspase $(\mathrm{P}<0,05)$.

A

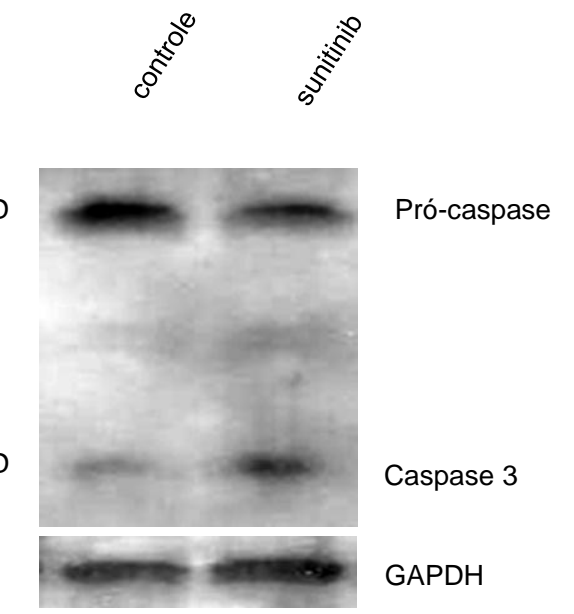

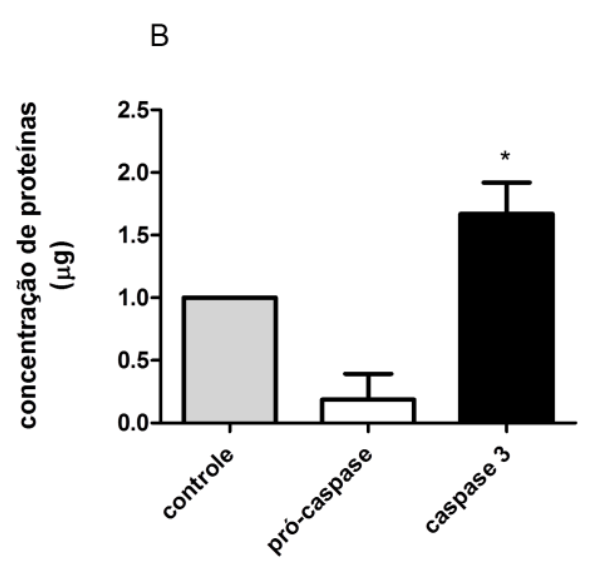

Figura 15: Ensaio da avaliação da expressão da proteína caspase 3 da via da apoptose das de células PC12-Adh tratadas com sunitinib $8.23 \mu \mathrm{M}$ por $48 \mathrm{~h}(40 \mu \mathrm{g}$ de proteínas). A - Imagem representativa de 1 experimento. B - Quantificação das bandas de 3 experimentos independentes $\left({ }^{*} \mathrm{P}<0,05\right)$. 
Nos experimentos anteriores, foi observado que a metformina reduz a viabilidade das células PC12-Adh em $40 \%$ com tratamento feito por $48 \mathrm{~h}$ com a concentração de $20,85 \mathrm{mM}$. Para investigar se a metformina poderia interferir na expressão de proteínas da via da apoptose das células PC12-Adh, foi realizado o ensaio de Western blot com anticorpo anticaspase 3 que reconhece proteínas caspase 3 da via da apoptose. Os resultados mostrados na Figura 16 sugerem que a metformina aumenta a expressão de proteínas caspase 3 clivada quando tratadas com a concentração de $20,85 \mathrm{mM}$ por $48 \mathrm{~h}$.
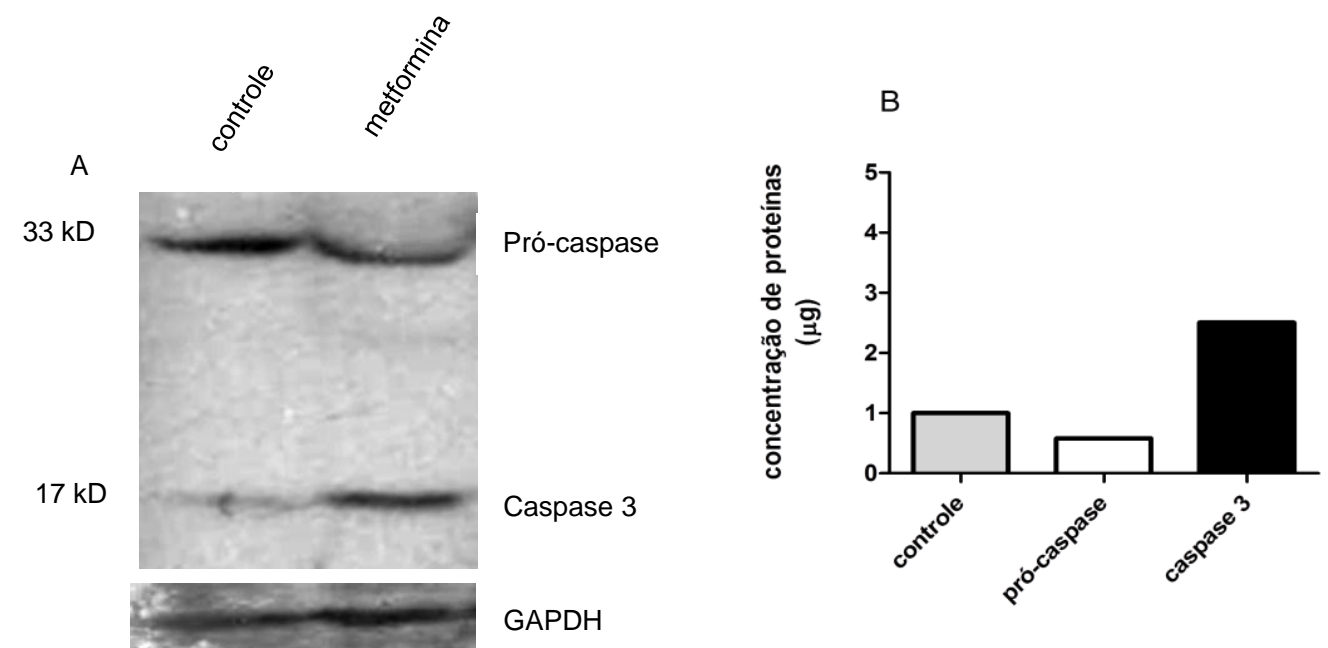

Figura 16: Ensaio da avaliação da expressão da proteína caspase 3 da via da apoptose das células PC12-Adh tratadas com metformina $20.85 \mathrm{mM}$ por $48 \mathrm{~h}$ ( $40 \mu \mathrm{g}$ de proteínas). A - Imagem representativa de 1 experimento. B -Quantificação das bandas de 1 experimento. 


\section{DISCUSSÃO}

O câncer é uma doença de alta complexidade. Opções terapêuticas ainda são limitadas e variam conforme sua origem e comportamento biológico. Nesse sentido, novas opções de tratamento vem sendo exploradas, que busquem aumentar a eficácia do tratamento e diminuir os efeitos adversos. Neste contexto, a inclusão de alternativas terapêuticas seguras e eficazes, adjuvantes, curativas ou que visem aumentar a sobrevida do paciente com qualidade de vida é necessária (78).

A metformina é o antidiabético oral mais prescrito para o tratamento do Diabetes Mellitus devido a sua segurança e eficácia no controle glicemico (53). Diversos estudos clínicos apontaram para associação entre o uso de metformina e a redução e prevenção na progressão em diferentes tipos de câncer $(7,59-66)$. O efeito citotóxico desse fármaco em células tumorais tem sido explorado, mais amplamente, a partir de estudos in vitro, porém, em alguns tipos de câncer, seus efeitos e mecanismos farmacológicos ainda não foram totalmente esclarecidos.

\section{Inibição da viabilidade celular induzida pela metformina em linhagens de adenocarcinoma de próstata (LNCaP e PC3)}

O câncer de próstata está entre os mais prevalentes na população geral. A maioria tem bom prognóstico, quando diagnosticado precocemente, porém, em muitos casos não ocorre resposta terapêutica adequada e a doença evoluiu, o que piora o prognóstico do paciente. Tumores mais responsivos ao tratamento, normalmente são tumores mais diferenciados, que possuem características mais semelhantes aos tecidos normais (79). No presente estudo, utilizou-se inicialmente a linhagem celular LNCaP, um tipo de célula de adenocarcinoma de próstata bem diferenciado, isso é, com várias características próximas as células de próstata normal, basicamente no que diz respeito à expressão de receptores hormonais. Essa linhagem expressa a proteína AR (androgen receptor), a qual constitui alvo terapêutico já bem estabelecido (13). 
No presente trabalho, quando essas células andrógeno-sensíveis foram submetidas ao tratamento com bicalutamida na concentração de $100 \mu \mathrm{M}$, a viabilidade celular foi reduzida em $60 \%$, o que está de acordo com estudos anteriores e valida o método utilizado nos ensaios realizados (Figura 9A) (13-15).

Nessa mesma linhagem (LNCaP), a metformina reduziu a viabilidade celular em $97 \%$ com o tratamento feito por $48 \mathrm{~h}$ usando concentração de até $20 \mathrm{mM}$ (Figura 9B). Colquhoun e colaboradores mostraram redução da viabilidade das células LNCaP em 95\% utilizando metformina na concentração de $10 \mathrm{mM}$ em um tratamento feito por 5 dias, determinado por ensaio clonogênico. Neste mesmo trabalho foi feita a associação da metformina e bicalutamida, a qual mostrou a redução da viabilidade dessas mesmas células em até 100\% (13). Sahra e colaboradores, utilizando azul de tripan para avaliar a viabilidade, também verificaram diminuição da viabilidade celular de $70 \%$ na linhagem $\mathrm{LNCaP}$ com uma concentração de $5 \mathrm{mM}$ de metformina (15). O presente estudo, portanto, corrobora a expressiva redução da viabilidade em células $\mathrm{LNCaP}$ induzida por metformina, que variou entre 70 e $97 \%$, quando utilizada em diferentes concentrações, diferentes tempos de tratamento e métodos de análise.

Com a finalidade de observar se o efeito sobre a viabilidade das células LNCaP estaria relacionado à presença do receptor de androgênios optou-se em realizar o mesmo ensaio, com as mesmas concentrações, em outra linhagem de câncer de próstata, a PC3. Esta linhagem é menos diferenciada, isso é, um tipo de câncer que perdeu características de células normais de próstata, sendo mais resistentes à terapia de privação androgênica. Essas células não expressam receptor de andrógeno (13). Nessa linhagem (PC3), a inibição da viabilidade celular induzida pelo tratamento com metformina por $48 \mathrm{~h}$ na concentração máxima de $20 \mathrm{mM}$ foi de apenas $20 \%$, o que é considerado um efeito muito pequeno, a despeito das altas concentrações de metformina utilizadas. Por outro lado, uma melhor resposta foi obtida com tratamento usando bicalutamida nas concentrações entre $1 \mu \mathrm{M}$ a $100 \mu \mathrm{M}$, a qual inibiu a viabilidade celular em $40 \%$ no tratamento feito por $48 \mathrm{~h}$. Em contraste com os resultados do presente estudo, em células PC-3, Colquhoun e colaboradores mostraram a inibição de $60 \%$ da viabilidade celular usando concentração máxima de $10 \mathrm{mM}$ de metformina, enquanto redução da viabilidade foi mínima (20\%), quando tratadas com bicalutamida (13). 
No presente estudo, as diferentes respostas verificadas na viabilidade celular de linhagens LNCaP e PC3 (redução de $97 \%$ e $20 \%$, respectivamente) após tratamento com metformina sugerem que esse efeito possivelmente é mediado ou ocorre por interferência em vias relacionadas ao AR. Ummuhan Demir e colaboradores demonstraram que a metformina interfere na síntese do receptor de androgênio, diminuindo os níveis dessa proteína e consequentemente diminuindo a sinalização desse receptor que funciona como fator de crescimento celular para as células prostáticas neoplásicas (80).

\section{Inibição da viabilidade celular em linhagem celular de feocromocitoma}

As células PC12-Adh são células de feocromocitoma que se caracterizam por secretarem dopamina e norepinefrina, porém, não produzem epinefrina. São células de origem neuroendócrina, obtidas a partir de um tumor adrenal de rato. Apresentam características morfológicas e citoquímicas semelhantes a células de feocromocitoma humano, bem como de medula adrenal normal (81). Essa linhagem tem sido útil para estudo dos processos de síntese, armazenamento e secreção de catecolaminas, e também do transportadores intracelulares de noradrenalina. Contudo, ao contrário da maioria das células cromafins normais, as células PC12Adh têm expressão muito baixa ou ausente da enzima feniletanolamina- $\mathrm{N}$ metiltransferase (PNMT- phenylethanolamine-N-methyltransferase), que é responsável pela síntese de adrenalina a partir da noradrenalina. Assim, essas células têm um fenótipo tipicamente noradrenérgico. Quando tratadas com fator de crescimento neural (NGF - nerve growth factor), essas células diferenciam-se facilmente em neurônios, com desenvolvimento de neuritos, parada no ciclo celular e aumento da expressão de catecolaminas. $O$ tratamento com dexametasona induz um fenótipo neuroendócrino típico de células cromafins (81). Assim, embora venham sendo utilizadas há vários anos, a grande plasticidade fenotípica das células PC12Adh limita conclusões definitivas sobre a eficácia de medicamentos antineoplásicos in vitro (82). 
Em 2000, foi obtida uma linhagem celular de feocromocitoma de camundongo, chamada MPC (mouse pheochromocytoma), derivada de animais knockout para o gene nf1 (neurofibromatose 1 gene). A neurofibromatose em seres humanos cursa frequentemente com feocromocitoma. Essa linhagem tem se mostrado complementar à PC12, uma vez que expressa a enzima da biossíntese de adrenalina, PNMT, e também altos níveis do receptor do tipo tirosina-quinase, RET (rearranged during transfection protooncogene), o qual transmite sinais originários da membrana para o crescimento e proliferação celular. O RET é um protooncogene, que, quando ativado constitutivamente, está associado ao desenvolvimento de vários tumores, incluindo feocromocitomas. Derivada de células MPC, outra linhagem foi obtida de um tumor metastático induzido no camundongo com knockout do nf1 (MTT - Mouse tumor tissue)(83).

As células MPC e MTT são similares a alguns feocromocitomas humanos, tanto do ponto de vista bioquímico quanto molecular. São facilmente visualizadas e respondem a terapias. Atualmente são consideradas modelo mais adequado para que avaliam a eficácia e alvos farmacológicos de novos tratamentos (83). Recentemente foi gerada uma linhagem de células imortalizadas originárias de células precursores obtidas de um feocromocitoma humano (hPhe01)(84). Contudo, tais células ainda não estão disponíveis comercialmente.

No presente estudo, células PC12 não diferenciadas em neurônios, que mantinham aspecto morfológico de células cromafins, foram estudadas e mostraramse sensíveis a um efeito inibidor da metformina sobre a viabilidade celular, o que foi bastante promissor. Nessas células, o tratamento com metformina por $48 \mathrm{~h}$ resultou em redução da viabilidade celular de até $40 \%$, com $\mathrm{Cl}_{50}=20,85 \mathrm{mM}$. Considerando que o sunitinib, um fármaco já utilizado em alguns casos de feocromocitoma maligno na prática clínica, reduziu a viabilidade celular em $60 \%$ com tratamento feito por $48 \mathrm{~h}$ $\left(\mathrm{Cl}_{50}=8,23 \mu \mathrm{M}\right)$, considera-se expressiva a redução de $40 \%$, induzida pela metformina.

Os efeitos da metformina em células de feocromocitoma estão em consonância com os resultados de Kumar e colaboradores. Esse autores apresentaram, em um estudo feito com metformina em células de neuroblastoma, uma redução da viabilidade celular em $60 \%$ usando ensaio de azul de tripan (16). 
Neuroblastomas (39) têm a mesma origem embrionária que os feocromocitomas, assim como os gliomas(85), sendo ambos também derivados de células primordiais existentes na crista neural. Costa e colaboradores também demonstraram que a metformina induzia a morte celular em células de neuroblastoma ( $\mathrm{SH}-\mathrm{SY} 5 \mathrm{Y}$ ), usando o ensaio de marcação nuclear SYTOX, analisado por citometria de fluxo (17).

O fato de as células utilizadas terem apresentado redução da viabilidade após tratamento com sunitinib está também de acordo com os dados de Saito e colaboradores, que mostraram o efeito de $1000 \mathrm{nM}$ de sunitinib em células PC12-Adh e observaram redução de viabilidade celular em $20 \%$ também usando ensaio do MTT(32). Denorme e colaboradores demostraram que o efeito do sunitinib sobre células da linhagem PC12-Adh foi superior ao do sorafenib, mostrando uma redução da viabilidade celular em $100 \%$ quando tratadas por 72 horas (28). A concordância desses resultados com os do presente estudo suportam a adequação do método utilizado para análise da viabilidade celular, do modelo in vitro e do comportamento biológico da linhagem celular utilizada nos experimentos.

Efeitos clínicos do sunitinib têm sido já bastante investigados e corroboram seu uso como fármaco de referencia no presente estudo. Hahn e colaboradores descreveram uma paciente com feocromocitoma agressivo, a qual teve melhor resposta ao tratamento com sunitinib quando comparado à quimioterapia convencional (86). Camilo Jimenez e colaboradores demonstraram evidencias de efeito do sunitinib em pacientes com feocromocitoma (87), enquanto em outro estudo, os tumores responderam bem ou parcialmente ao tratamento (88).

Para confirmação desses efeitos, seria interessante confirmar o estado de diferenciação neuroendócrina das passagens de células PC12 utilizadas, e ainda, investigar se o efeito inibidor da metformina ocorre também nas demais linhagens de feocromocitoma MPC e MTT(49).

A associação da metformina em concentrações variáveis com sunitinib, na $\mathrm{Cl}_{50}$, mostrou resultados que devem ser analisados com maior detalhamento. Curiosamente, observou-se aparente predomínio do efeito inibitório da metformina sobre a viabilidade celular, em detrimento da redução de viabilidade provocada pelo sunitinib isoladamente, que havia atingido até $43 \%$. Diferentemente do achado na curva dose-resposta com metformina isoladamente, nas menores concentrações de 
metformina, entre 1 e $5 \mathrm{mM}$, houve um reestabelecimento da viabilidade celular das células PC12-Adh, quando tratadas concomitantemente com sunitinib (Figura 12A). Para avaliar melhor esse efeito, em um segundo experimento, a concentração do sunitinib foi elevada a $20 \mu \mathrm{M}$ e as concentrações da metformina permaneceram iguais (entre 1 e $30 \mathrm{mM}$ ). Observou-se que mesmo utilizando concentração mais elevada de sunitinib houve interferência da metformina sobre o efeito inibidor da viabilidade celular induzido pelo sunitinib. Em outras palavras, a metformina aparentemente reduziu ou impediu o efeito do sunitinib. Interessantemente, Janjetovic e colaboradores mostraram em um estudo feito com células de glioma, neuroblastoma, fibrosarcoma e em linhagem de células de leucemia, que a metformina reduziu in vitro o efeito antitumoral da cisplatina por uma via independente do AMPK (89). Considerando que pacientes com feocromocitoma frequentemente desenvolvem diabetes secundário à hipersecreção de catecolaminas, é necessário avaliar se o uso de metformina poderia interferir negativamente nos efeitos do sunitinib, caso ambos sejam usados concomitantemente. Futuros estudos que avaliem as vias de sinalização que sofrem interferência da metformina e do sunitinib em células de feocromocitoma são necessários para esclarecer esse efeito.

A metformina já foi associada a outros fármacos para o tratamento de diversos cânceres. No estudo realizado por Colquhoun e colaboradores, observouse que a metformina potencializou o efeito da bicalutamida na redução da viabilidade de células de adenocarcinoma de próstata (13). Inversamente, Groenendijk e colaboradores descreveram que a associação de metformina e sorafemib, um outro inibidor de tirosina-quinase, gerou um sinergismo na ativação da AMPK e diminuição da ativação de proteínas da via de crescimento celular (90). Minematsu e colaboradores relataram em seus estudos que o sunitinib inibe os transportadores OCTS, responsáveis pela entrada de metformina nas células (91). Assim, estudos futuros são necessários para esclarecimento das interações entre metformina e os inibidores de tirosina quinase, especialmente o sunitinib.

A determinação dos efeitos de fármacos sobre o ciclo celular de células neoplásicas é importante. Por meio deste ensaio é possível verificar se as células estão em constante divisão e síntese de proteínas necessárias para o crescimento celular ou se elas se encontram restritas à fase que indica senescência celular, isto 
é, quando as células completam o seu ciclo celular, param de proliferar e iniciam um processo de morte natural (92).

O ensaio feito para investigar o efeito da metformina sobre os eventos do ciclo celular das células PC12-Adh, sendo o tratamento na concentração de 20,85mM de metformina, não mostrou estabilização do ciclo celular na fase G0/G1, isto é, a metformina não alterou o ciclo celular das células PC12-Adh com tratamento de 48h. Quando foram tratadas com sunitinib houve um discreto aumento na proporção de células na fase $G 0 / G 1$, porém esse dado não foi estatisticamente significante. Em contraste, Isakovic e colaboradores investigaram o efeito da metformina em células de glioma usando concentração de $4 \mathrm{mM}$ e observaram que a metformina induziu a parada do ciclo celular na fase G0/G1(85).

Por fim, foram investigados os efeitos da metformina na expressão de caspase 3 , uma proteína da via da apoptose, das células PC12-Adh. Para o tratamento foi usada concentração de metformina de $20,85 \mathrm{mM}$ (concentração da $\mathrm{Cl}_{50}$ encontrada no ensaio de viabilidade celular) por 48h e o resultado exibiu redução da prócaspase e aumento da caspase clivada quando comparadas ao controle sem tratamento. O mesmo efeito pôde ser comprovado quando foi utilizado o sunitinib na concentração de $8,23 \mu \mathrm{M}$, que diminuiu a expressão de pró-caspase e aumento da caspase clivada, sendo esse dado estatisticamente significante $(P<0,05)$. Esse resultado confirma que o sunitinib induz a apoptose via caspase 3 . Dulovic e colaboradores mostraram que a metformina induz a morte celular programada em linhagem de células de neuroblatoma por ativação da via AMPK/mTOR (93). O achado do presente estudo é compatível com o efeito de inibição da viabilidade da metformina em células PC12, porém requer estudos adicionais com outros marcadores de apoptose para confirmação.

Denorme e colaboradores mostraram, em um estudo feito com sunitinib nas concentrações de 10, 20 e 30 $\mu \mathrm{M}$ por até $24 \mathrm{~h}$ em células PC12-Adh, um aumento da atividade de caspase $3 / 7$ em 6 vezes, o que está em conformidade com os resultados do presente estudo (28). Kumar e colaboradores também demonstraram que a metformina induzia a clivagem da caspase $3 \mathrm{em}$ células de neuroblastoma(16). Contrapondo esses dados, Costa e colaboradores encontraram 
que a metformina na concentração de $20 \mathrm{mM}$ não interferiu na expressão de caspase clivada em células de neuroblastoma (17).

O efeito inibidor da metformina sobre a viabilidade de células de feocromocitoma in vitro aqui demonstrado é promissor e requer experimentos adicionais para esclarecimento. Considerando que a maioria dos efeitos antineoplásicos da metformina já bem definidos envolve a inibição do complexo enzimático mitocondrial 1 da cadeia de transporte de elétrons, o resultante estresse energético induzido nas células neoplásicas pela metformina possivelmente compromete a eficiência dos mecanismos de sobrevivência dessas células, mediado pelo efeito Warburg, com ainda maior desregulação das vias de glicólise oxidativa. Além disso, especificamente no caso de feocromocitomas, é possível que o bloqueio do complexo 1, associado ao bloqueio do complexo 2 (succinato desidrogenase) intrinsecamente observado nos tumores com mutações nas subunidades de SDH (succinato desidrogenase), pode representar um mecanismo interessante, cuja eficiência alvo direcionada merece ser melhor esclarecida. 


\section{CONCLUSÃO}

Os resultados do presente estudo demonstraram que a metformina inibiu a viabilidade celular de células de adenocarcinoma de próstata andrógeno-sensível (LNCaP) e de feocromocitoma (PC12-Adh), de maneira dose-dependente em até $97 \%$ e $40 \%$, respectivamente. Em linhagem de adenocarcinoma de próstata resistente a andrógenos (PC3), não se observou efeito inibidor expressivo (efeito máximo de $20 \%$ de inibição de viabilidade).

Além disso, a metformina inibiu o efeito redutor da viabilidade induzido pelo sunitinib. A metformina não alterou o ciclo celular das células PC12-Adh quando o tratamento foi feito por $48 \mathrm{~h}$, porém aumentou a expressão de proteínas da via da apoptose, as caspases 3 , sugerindo efeito pró-apoptótico sobre essas células. 


\section{REFERÊNCIAS}

1. Brasil. Ministério da Saúde: Incidência de câncer no Brasil [cited 2015]. Available from: http://www.inca.gov.br/estimativa/2014.

2. Croce CM. Viral subversion of apoptotic enzymes: escape from death row. The New England journal of medicine. 2008;62:171-92.

3. Hoffman RM. Metformin, independent of AMPK, induces mTOR inhibition and cellcycle arrest through REDD1. The New England journal of medicine. 2011;71:436672.

4. Pacak K. Phaeochromocytoma: a catecholamine and oxidative stress disorder. Endocrine regulations. 2011;45:65-90.

5. Lenders JW. Pheochromocytoma and paraganglioma: an endocrine society clinical practice guideline. 2014;99:1915-42.

6. Ferrannini E. Both sunitinib and sorafenib are effective treatments for pheochromocytoma in a xenograft model. The New England journal of medicine. 2014;352(2):236-44.

7. Pierotti MA, Berrino F, Gariboldi M, Melani C, Mogavero A, Negri T, et al. Targeting metabolism for cancer treatment and prevention: metformin, an old drug with multi-faceted effects. Oncogene. 2012;32:1475-87.

8. Gong J, Robbins LA, Lugea A, Waldron RT, Jeon CY, Pandol SJ. Diabetes, pancreatic cancer, and metformin therapy. Frontiers in physiology. 2014;5:426.

9. Schmedt N, Azoulay L, Hense S. Re: "reduced risk of lung cancer with metformin therapy in diabetic patients: a systematic review and meta-analysis". American journal of epidemiology [Internet]. 2014; 180(12):[1216-7 pp.].

10.Joost HG. The target of metformin in type 2 diabetes. Diabetes \& vascular disease research : official journal of the International Society of Diabetes and Vascular Disease. 2014;371(16):1547-8.

11.Zi FM, He JS, Li Y, Wu C, Yang L, Yang Y, et al. Metformin displays anti-myeloma activity and synergistic effect with dexamethasone in in vitro and in vivo xenograft models. Cancer letters. 2014;356:443-53.

12.Dowling RJ, Niraula S, Stambolic V, Goodwin PJ. Metformin in cancer: translational challenges. Journal of molecular endocrinology. 2012;48:R31-43.

13.Colquhoun AJ, Venier NA, Vandersluis AD, Besla R, Sugar LM, Kiss A, et al. Metformin enhances the antiproliferative and apoptotic effect of bicalutamide in prostate cancer. Prostate cancer and prostatic diseases. 2012;15:346-52.

14.Ben Sahra I, Regazzetti C, Robert G, Laurent K, Le Marchand-Brustel Y, Auberger $P$, et al. Metformin, independent of AMPK, induces mTOR inhibition and cell-cycle arrest through REDD1. Cancer research. 2011;71:4366-72.

15.Ben Sahra I, Laurent K, Giuliano S, Larbret F, Ponzio G, Gounon P, et al. Targeting cancer cell metabolism: the combination of metformin and 2-deoxyglucose 
induces p53-dependent apoptosis in prostate cancer cells. Cancer research. 2010;70:2465-75.

16.Kumar A, Al-Sammarraie N, DiPette DJ, Singh US. Metformin impairs Rho GTPase signaling to induce apoptosis in neuroblastoma cells and inhibits growth of tumors in the xenograft mouse model of neuroblastoma. Oncotarget. 2014;5:1170922.

17.Costa D, Gigoni A, Wurth R, Cancedda R, Florio T, Pagano A. Metformin inhibition of neuroblastoma cell proliferation is differently modulated by cell differentiation induced by retinoic acid or overexpression of NDM29 non-coding RNA. Cancer cell international. 2014;14:59.

18. Elsada A, Pearce F, George E, Adler A. NICE guidance on enzalutamide for metastatic hormone-relapsed prostate cancer. The Lancet Oncology. 2014;15:10589.

19.Hoffman RM. Clinical practice. Screening for prostate cancer. The New England journal of medicine. 2011;365:2013-9.

20.Hussain M, Tangen CM, Berry DL, Higano CS, Crawford ED, Liu G, et al. Intermittent versus continuous androgen deprivation in prostate cancer. The New England journal of medicine. 2013;368:1314-25.

21.Attar RM, Takimoto $\mathrm{CH}$, Gottardis MM. Castration-resistant prostate cancer: locking up the molecular escape routes. Clinical cancer research : an official journal of the American Association for Cancer Research. 2009;15:3251-5.

22.Micromedex. Bicalutamide 2015. Available from: http://www.micromedex.com.

23.McLeod DG, Iversen P, See WA, Morris T, Armstrong J, Wirth MP. Bicalutamide $150 \mathrm{mg}$ plus standard care vs standard care alone for early prostate cancer. BJU international. 2006;97:247-54.

24.Scher HI, Fizazi K, Saad F, Taplin ME, Sternberg CN, Miller K, et al. Increased survival with enzalutamide in prostate cancer after chemotherapy. The New England journal of medicine. 2012;367:1187-97.

25.Farrow JM, Yang JC, Evans CP. Autophagy as a modulator and target in prostate cancer. Nature reviews Urology. 2014;11:508-16.

26.Tucci M, Scagliotti GV, Vignani F. Metastatic castration-resistant prostate cancer: time for innovation. Future oncology (London, England). 2015;11:91-106.

27.Dahia PL. Pheochromocytoma and paraganglioma pathogenesis: learning from genetic heterogeneity. Nature reviews Cancer. 2014;14:108-19.

28.Denorme M, Yon L, Roux C, Gonzalez BJ, Baudin E, Anouar Y, et al. Both sunitinib and sorafenib are effective treatments for pheochromocytoma in a xenograft model. Cancer letters. 2014;352:236-44.

29.Lenders JW, Duh QY, Eisenhofer G, Gimenez-Roqueplo AP, Grebe SK, Murad $\mathrm{MH}$, et al. Pheochromocytoma and paraganglioma: an endocrine society clinical practice guideline. The Journal of clinical endocrinology and metabolism. 2014;99:1915-42. 
30.Parenti G, Zampetti B, Rapizzi E, Ercolino T, Giache V, Mannelli M. Updated and new perspectives on diagnosis, prognosis, and therapy of malignant pheochromocytoma/paraganglioma. Journal of oncology. 2012;2012:872713.

31.Chen H, Sippel RS, O'Dorisio MS, Vinik Al, Lloyd RV, Pacak K. The North American Neuroendocrine Tumor Society consensus guideline for the diagnosis and management of neuroendocrine tumors: pheochromocytoma, paraganglioma, and medullary thyroid cancer. Pancreas. 2010;39:775-83.

32.Saito Y, Tanaka Y, Aita Y, Ishii KA, Ikeda T, Isobe K, et al. Sunitinib induces apoptosis in pheochromocytoma tumor cells by inhibiting VEGFR2/Akt/mTOR/S6K1 pathways through modulation of $\mathrm{Bcl}-2$ and BAD. American journal of physiology Endocrinology and metabolism. 2011;302:E615-25.

33.Faivre S, Delbaldo C, Vera K, Robert C, Lozahic S, Lassau N, et al. Safety, pharmacokinetic, and antitumor activity of SU11248, a novel oral multitarget tyrosine kinase inhibitor, in patients with cancer. Journal of clinical oncology : official journal of the American Society of Clinical Oncology. 2005;24:25-35.

34.Kerbel RS. Tumor angiogenesis. The New England journal of medicine. 2008;358:2039-49.

35.Raymond E, Dahan L, Raoul JL, Bang YJ, Borbath I, Lombard-Bohas C, et al. Sunitinib malate for the treatment of pancreatic neuroendocrine tumors. The New England journal of medicine. 2011;364:501-13.

36.Sharma K, Suresh PS, Mullangi R, Nuggehally SR. Quantitation of VEGFR2 (vascular endothelial growth factor receptor) inhibitors - review of assay methodologies and perspectives. Biomedical chromatography : BMC. 2014.

37.Bajetta E, Guadalupi V, Procopio G. Activity of sunitinib in patients with advanced neuroendocrine tumors. Journal of clinical oncology : official journal of the American Society of Clinical Oncology. 2009;27(2):319-20; author reply 20.

38.Wolter P, Dumez H, Schoffski P. Sunitinib and hypothyroidism. The New England journal of medicine. 2007;356(15):1580; author reply -1.

39.Del Barco S, Vazquez-Martin A, Cufi S, Oliveras-Ferraros C, Bosch-Barrera J, Joven $\mathrm{J}$, et al. Metformin: multi-faceted protection against cancer. Oncotarget. 2011;2:896-917.

40.Santomauro Jún AC, Ugolini MR, Santomauro AT, Souto RPd. Metformina e AMPK: um antigo fármaco e uma nova enzima no contexto da síndrome metabólica. Arq bras endocrinol metab. 2008;52:120-5.

41.Pernicova I, Korbonits M. Metformin--mode of action and clinical implications for diabetes and cancer. Nature reviews Endocrinology. 2014;10:143-56.

42.American Diabetes A. Diagnosis and classification of diabetes mellitus. Diabetes care. 2014;37:S81-S90.

43.Claudio IDLP. Efeito antigenotóxico da metformina no Diabetes Mellitus. 2005.

44.But A, Wang H, Mannisto S, Pukkala E, Haukka J. Assessing the effect of treatment duration on the association between anti-diabetic medication and cancer risk. PloS one. 2014;9:e113162. 
45.Bertoldo MJ, Faure M, Dupont J, Froment P. Impact of metformin on reproductive tissues: an overview from gametogenesis to gestation. Annals of translational medicine. 2014;2:55.

46. Rovaris DL, Grohe R, Santos B, Perassolo MS, de Andrade FM. Metformina e Diabetes Melito Tipo 2: Passado, Presente e Farmacogética. Clinical and Biomedical Research.30(4).

47.El-Sharkawy AA, Abdelmotaleb GS, Aly MK, Kabel AM. Effect of metformin on sleep disorders in adolescent girls with polycystic ovarian syndrome. Journal of pediatric and adolescent gynecology. 2014;27:347-52.

48.Nasri H, Rafieian-Kopaei M. Metformin: Current knowledge. Journal of research in medical sciences : the official journal of Isfahan University of Medical Sciences. 2014;19:658-64.

49.Aljada A, Mousa SA. Metformin and neoplasia: implications and indications. Pharmacology \& therapeutics. 2011;133:108-15.

50.Brietzke SA. Effect of metformin on sleep disorders in adolescent girls with polycystic ovarian syndrome. The Medical clinics of North America. 2014;27(6):34752.

51.Brietzke SA. Oral antihyperglycemic treatment options for type 2 diabetes mellitus. The Medical clinics of North America. 2014;99:87-106.

52.Salpeter SR, Greyber E, Pasternak GA, Salpeter EE. Risk of fatal and nonfatal lactic acidosis with metformin use in type 2 diabetes mellitus. The Cochrane database of systematic reviews. 2010:Cd002967.

53.Peron EP, Ogbonna KC, Donohoe KL. Antidiabetic medications and polypharmacy. Clinics in geriatric medicine. 2014;31:17-27, vii.

54.Miller RA, Chu Q, Xie J, Foretz M, Viollet B, Birnbaum MJ. Biguanides suppress hepatic glucagon signalling by decreasing production of cyclic AMP. Nature. 2013;494:256-60.

55.Ferrannini E. The target of metformin in type 2 diabetes. The New England journal of medicine. 2014;371:1547-8.

56.Kraut JA, Madias NE. Lactic acidosis. The New England journal of medicine. 2014;371:2309-19.

57.Nelson L, Cox M. Lehninger Principles of Biochemistry. 4 ed. Freeman, Freeman, editors2005.

58.Madiraju AK, Erion DM, Rahimi Y, Zhang XM, Braddock DT, Albright RA, et al. Metformin suppresses gluconeogenesis by inhibiting mitochondrial glycerophosphate dehydrogenase. Nature. 2014;510:542-6.

59.El-Benhawy SA, El-Sheredy HG. Metformin and survival in diabetic patients with breast cancer. The Journal of the Egyptian Public Health Association. 2014;89:14853.

60.Bensimon L, Yin H, Suissa S, Pollak MN, Azoulay L. The use of metformin in patients with prostate cancer and the risk of death. Cancer epidemiology, biomarkers \& prevention : a publication of the American Association for Cancer Research, cosponsored by the American Society of Preventive Oncology. 2014;23:2111-8. 
61. Hosono K, Endo H, Takahashi H, Sugiyama M, Sakai E, Uchiyama T, et al. Metformin suppresses colorectal aberrant crypt foci in a short-term clinical trial. Cancer prevention research (Philadelphia, Pa). 2010;3:1077-83.

62.Bodmer M, Becker C, Meier C, Jick SS, Meier CR. Use of antidiabetic agents and the risk of pancreatic cancer: a case-control analysis. The American journal of gastroenterology. 2012;107:620-6.

63.Anwar MA, Kheir WA, Eid S, Fares J, Liu X, Eid AH, et al. Colorectal and Prostate Cancer Risk in Diabetes: Metformin, an Actor behind the Scene. Journal of Cancer. 2014;5:736-44.

64.Giovannucci E, Harlan DM, Archer MC, Bergenstal RM, Gapstur SM, Habel LA, et al. Diabetes and cancer: a consensus report. CA: a cancer journal for clinicians. 2010;60:207-21.

65.Pollak M. Metformin and other biguanides in oncology: advancing the research agenda. Cancer prevention research (Philadelphia, Pa). 2010;3:1060-5.

66.Singh S, Singh H, Singh PP, Murad MH, Limburg PJ. Antidiabetic medications and the risk of colorectal cancer in patients with diabetes mellitus: a systematic review and meta-analysis. Cancer epidemiology, biomarkers \& prevention : a publication of the American Association for Cancer Research, cosponsored by the American Society of Preventive Oncology. 2013;22:2258-68.

67.Bowker SL, Majumdar SR, Veugelers P, Johnson JA. Increased cancer-related mortality for patients with type 2 diabetes who use sulfonylureas or insulin. Diabetes care. 2006;29:254-8.

68.Smeitink J, van den Heuvel L, DiMauro S. The genetics and pathology of oxidative phosphorylation. Nature reviews Genetics. 2001;2:342-52.

69.Zhang Y, Storr SJ, Johnson K, Green AR, Rakha EA, Ellis IO, et al. Involvement of metformin and AMPK in the radioresponse and prognosis of luminal versus basal-like breast cancer treated with radiotherapy. Oncotarget. 2014;5:12936-49.

70.Zoncu R, Efeyan A, Sabatini DM. mTOR: from growth signal integration to cancer, diabetes and ageing. Nature reviews Molecular cell biology. 2010;12:21-35.

71.Pernicova I, Korbonits M. Metformin-mode of action and clinical implications for diabetes and cancer. Nature reviews Endocrinology. 2014;10:143-56.

72.Tadakawa M, Takeda T, Li B, Tsuiji K, Yaegashi N. The anti-diabetic drug metformin inhibits vascular endothelial growth factor expression via the mammalian target of rapamycin complex 1 /hypoxia-inducible factor-1alpha signaling pathway in ELT-3 cells. Molecular and cellular endocrinology. 2014;399:1-8.

73.Horoszewicz JS, Leong SS, Kawinski E, Karr JP, Rosenthal H, Chu TM, et al. LNCaP model of human prostatic carcinoma. Cancer research. 1983;43:1809-18.

74.Perkel VS, Mohan S, Herring SJ, Baylink DJ, Linkhart TA. Human prostatic cancer cells, PC3, elaborate mitogenic activity which selectively stimulates human bone cells. Cancer research. 1990;50:6902-7.

75.Peng $L$, Wang B, Ren P. Reduction of MTT by flavonoids in the absence of cells. Colloids and surfaces B, Biointerfaces. 2005;45:108-11. 
76.Muraina IA, Suleiman MM, Eloff JN. Can MTT be used to quantify the antioxidant activity of plant extracts? Phytomedicine : international journal of phytotherapy and phytopharmacology. 2009;16:665-8.

77.Lowry OH, Rosebrough NJ, Farr AL, Randall RJ. Protein measurement with the Folin phenol reagent. The Journal of biological chemistry. 1951;193:265-75.

78.Joost HG. Diabetes and cancer: epidemiology and potential mechanisms. Diabetes \& vascular disease research : official journal of the International Society of Diabetes and Vascular Disease. 2014;11:390-4.

79.Croce CM. Oncogenes and cancer. The New England journal of medicine. 2008;358:502-11.

80.Demir U, Koehler A, Schneider R, Schweiger S, Klocker H. Metformin anti-tumor effect via disruption of the MID1 translational regulator complex and AR downregulation in prostate cancer cells. BMC cancer. 2014;14:52.

81.Greene LA, Tischler AS. Establishment of a noradrenergic clonal line of rat adrenal pheochromocytoma cells which respond to nerve growth factor. Proceedings of the National Academy of Sciences of the United States of America. 1976;73:24248.

82.Dixon DN, Loxley RA, Barron A, Cleary S, Phillips JK. Comparative studies of PC12 and mouse pheochromocytoma-derived rodent cell lines as models for the study of neuroendocrine systems. In vitro cellular \& developmental biology Animal. 2005;41:197-206.

83.Korpershoek E, Pacak K, Martiniova L. Murine models and cell lines for the investigation of pheochromocytoma: applications for future therapies? Endocrine pathology. 2012;23:43-54.

84.Ghayee HK, Bhagwandin VJ, Stastny V, Click A, Ding LH, Mizrachi D, et al. Progenitor cell line (hPheo1) derived from a human pheochromocytoma tumor. PloS one. 2013;8:e65624.

85.Isakovic A, Harhaji L, Stevanovic D, Markovic Z, Sumarac-Dumanovic M, Starcevic V, et al. Dual antiglioma action of metformin: cell cycle arrest and mitochondria-dependent apoptosis. Cellular and molecular life sciences : CMLS. 2007;64:1290-302.

86.Hahn NM, Reckova M, Cheng L, Baldridge LA, Cummings OW, Sweeney CJ. Patient with malignant paraganglioma responding to the multikinase inhibitor sunitinib malate. Journal of clinical oncology : official journal of the American Society of Clinical Oncology. 2008;27:460-3.

87.Jimenez C, Cabanillas ME, Santarpia L, Jonasch E, Kyle KL, Lano EA, et al. Use of the tyrosine kinase inhibitor sunitinib in a patient with von Hippel-Lindau disease: targeting angiogenic factors in pheochromocytoma and other von Hippel-Lindau disease-related tumors. The Journal of clinical endocrinology and metabolism. 2008;94:386-91.

88.Joshua AM, Ezzat S, Asa SL, Evans A, Broom R, Freeman M, et al. Rationale and evidence for sunitinib in the treatment of malignant 
paraganglioma/pheochromocytoma. The Journal of clinical endocrinology and metabolism. 2008;94:5-9.

89.Janjetovic K, Vucicevic L, Misirkic M, Vilimanovich U, Tovilovic G, Zogovic N, et al. Metformin reduces cisplatin-mediated apoptotic death of cancer cells through AMPKindependent activation of Akt. European journal of pharmacology. 2010;651:41-50.

90.Groenendijk FH, Mellema WW, van der Burg E, Schut E, Hauptmann M, Horlings $\mathrm{HM}$, et al. Sorafenib synergizes with metformin in NSCLC through AMPK pathway activation. International journal of cancer Journal international du cancer. 2014;136:1434-44.

91.Minematsu T, Giacomini KM. Interactions of tyrosine kinase inhibitors with organic cation transporters and multidrug and toxic compound extrusion proteins. Molecular cancer therapeutics. 2011;10:531-9.

92.Alberts B, Jonhnson A, Lewis J, Raff M, Roberts K, Walter P. The molecular biology of the cell. 4 ed. New Yorque: Garland Science; 2002.

93.Dulovic M, Jovanovic M, Xilouri M, Stefanis L, Harhaji-Trajkovic L, Kravic-Stevovic $\mathrm{T}$, et al. The protective role of AMP-activated protein kinase in alpha-synuclein neurotoxicity in vitro. Neurobiology of disease. 2013;63:1-11. 